\title{
Sufism, Panislamism and Information Panic: Nil Sergeevich Lykoshin and the aftermath of the Andijan Uprising
}

\author{
Past \& Present No.214 (2012) pp.255 - 304
}

'This is why, on questions relating to the "mood" of the natives, Russian power felt itself to be entirely helpless. It was the main source of that panic which followed as a result of the Andijan uprising. This also explains why, notwithstanding the absolute calm in the region throughout the 1880s and 1890s, right up until the first flashes of the Andijan uprising, the authorities never ceased to repeat that, they may say things are quiet, but... anything might happen. ${ }^{1}$

The Bolshevik activist and historian Pyotr Galuzo published these lines in 1926, ten years after Tsarist authority in Central Asia had been rocked by a widespread revolt against the conscription of local Muslims into labour battalions, and almost thirty years since a Sufi spiritual leader called Muhammad Ali Sabyr, better known as the 'Dukchi Ishan', had led 2,000 of his followers in an attack on the Russian garrison of Andijan, a town at the eastern end of the Ferghana valley in modern-day Uzbekistan. For Galuzo these events were linked, not simply because they represented the most significant attempts at violent resistance to Russian rule in Central Asia before 1917, but because of their effect on official thinking. He argued that it was the Tsarist regime's panicked overreaction to Andijan which accelerated the distribution of firearms amongst Turkestan's small but growing population of Slavic settlers. This in turn allowed the latter to exact a terrible revenge on the Kazakhs and Kyrgyz of Semirechie for the 2,500 or so Europeans who were killed in the 1916 revolt, as thousands of nomads were massacred or driven into exile whilst their land was seized. ${ }^{2}$

Galuzo's is one of the earliest historical judgements on the origins, significance and impact of the Andijan uprising, an episode which has generated more debate than almost any other event from the fifty years of Russian colonial rule in Turkestan before the upheavals of the revolutionary period. His assessment was typical of early Soviet historiography which criticised Tsarist colonialism as brutal and exploitative, and he would later publish a still more polemical work denouncing the pre-revolutionary regime. ${ }^{3}$ Russophone historians of the Soviet era made little effort to establish the deeper motivations and causes of the Andijan uprising, instead interpreting it to suit whatever

The research for this article was funded by the Warden and Fellows of All Souls College, Oxford, and the British Academy. I would like to thank Sergei Abashin, Ulrich Hofmeister, Kimura Satoru, Mir Ahmed Mirhaldarov, Beatrice Penati, Oksana Pugovkina, Benedetta Rossi, Paolo Sartori, Shimada Shizuo, Shioya Akifumi, Uyama Tomohiko, and Tom Welsford for their help, advice and suggestions.

1 P. G. Galuzo Vooruzhenie russkikh pereselentsev v Srednei Azii [The arming of the Russian settlers in Central Asia] (Tashkent, 1926) p.24

${ }^{2}$ M. Buttino Revolyutsiya naoborot [A revolution in reverse](Moscow, 2008) pp.70-5; Jörn Happel Nomadische Lebenswelten und zarische Politik. Der Aufstand in Zentralasien 1916 (Wiesbaden, 2010)

${ }^{3}$ P. G. Galuzo Turkestan-Koloniya [Turkestan-Colony] (Moscow, 1929) 
'Sufism, Panislamism and Information Panic: Nil Sergeevich Lykoshin and the aftermath of the Andijan Uprising' Past \& Present No.214 (2012) pp.255 - 304

might be the prevailing historiographical orthodoxy. Until the late 1930s Soviet historians could still deem it a 'genuinely revolutionary' movement of the oppressed labouring classes in Ferghana, notwithstanding the 'religious colouring' which it took on, ${ }^{4}$ but by the 1950s it had been re-classed as 'reactionary' and there were hints of the involvement of British agents. ${ }^{5}$ A year after Galuzo's book appeared, Fazilbek Atabek oghli, the son of an Andijan qazi (Islamic judge) would publish a much more profound account of the uprising, ${ }^{6}$ based on works written by Muhammad Ali Sabyr himself (the didactic Ibrat alGhafilin), ${ }^{7}$ and by his followers (notably the Manaqib-i Dukechi Ishan, ${ }^{8}$ a hagiography and description of his miracles), together with documents from the period and interviews with eyewitnesses. These, together with Russian official sources, have formed the basis of the voluminous Western and post-Soviet historiography on the subject. ${ }^{9}$

The basic facts of the Andijan uprising are largely undisputed: it was bloody but brief. Twenty-two soldiers were killed and twenty wounded, but it had already been suppressed by the time the news of it reached Tashkent. ${ }^{10}$ Most of the debate has revolved around the character and motivations of its leader, and the degree to which he was the prime mover or a reluctant figurehead carried along by his followers. Muhammad Ali Sabyr, from the village of Ming-tepe in the Ferghana Valley, was sometimes known as 'Diwana' ('the mad or possessed of God'), but more commonly as the 'Dukchi Ishan' (dukchi means spindle-maker, his father's trade). The nature of his religious authority was complex. Ishan is an honorific applied to spiritual leaders in Central Asia, and whilst many

${ }^{4}$ E. Shteinberg (ed.) 'Andizhanskoe Vosstanie 1898g.' ['The Andijan Uprising of 1898'] Krasnyi Arkbiv (KA) Vol.91 (1938) pp.123-8

${ }^{5}$ Lowell Tillett The Great Friendship (Chapel Hill, NC, 1969) pp.174-5

${ }^{6}$ Fazilbek Atabek oghli Dukchi Ishan Vaqeasi (Farghanada istibdad jalladlari) [The Dukchi Ishan Affair (The atrocities of despotism in Ferghana)](Samarkand-Tashkent, 1927); my description of this work is taken from Hisao Komatsu 'The Andijan Uprising reconsidered' in Sato Tsugitaka (ed.) Muslim Societies: Historical and Comparative Perspectives (London, 2004) pp.30, 56 n.8

7 This remains unpublished: a copy of the manuscript is held at the Biruni Oriental Institute of the Uzbekistan Academy of Sciences in Tashkent (IVAN RUz MS No.1725)

8 A. von Kügelgen (ed.) \& B. A. Babadzhanov (trans.) Manaqib-i Dukechi Ishan (Almaty, 2004)

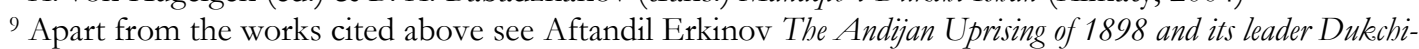
Ishan described by contemporary poets (Tokyo, 2009); idem 'Andizhanskoe vosstanie, ego predvoditel' v otsenkakh poetov epokhi' ['The Andijan Uprising, its leader in the judgement of the poets of the epoch'] Vestnik Evrazii (2003) No.1 pp.111-137; Bakhtiyar Babajanov 'Andizhanskoe vosstanie 1898 goda i “musul'manskii vopros" v Turkestane (vzglyady “kolonizatorov" i “kolonizirovannykh”)' [The Andijan Uprising of 1898 and the 'Muslim Question' in Turkestan (views of the "colonisers" and "colonised")] Ab Imperio (2009) No.2 pp.155-200; Idem 'Dukchi Ishan und der Aufstand von Andijan 1898' in Von Kügelgen et al (ed.): Muslim Culture in Russia and Central Asia (Berlin, 1998) Vol.II pp.167-191 \& Idem 'Dukchi Ishan i Andizhanskoe vosstanie 1898g.' ['Dukchi Ishan and the Andijan Uprising of 1898'] in S. N. Abashin \& V. N. Bobrovnikov (ed.) Podvizhniki Islama. Kult syyatykh i sufizm v Srednei Azii i na Kavkaze [Ascetics of Islam; the cult of the Saints and Sufism in Central Asia and the Caucasus] (Moscow, 2003) pp.251-77; For a full list of earlier publications relating to the uprising see Yuri Bregel's Bibliography of Islamic Central Asia (Bloomington, IN, 1995) Vol.I pp.620-1

10 'Bezporyadki v Fergane' ['Disorders in Ferghana'] Turkestanskiya Vedomosti (TV) 21 ${ }^{\text {st }}$ May 1898 No.37; V. P. Sal'kov "Andizhanskoe vosstanie" v $1898 g$ [The "Andijan uprising” in 1898] (Kazan, 1901) p.64 
'Sufism, Panislamism and Information Panic: Nil Sergeevich Lykoshin and the aftermath of the Andijan Uprising' Past \& Present No.214 (2012) pp.255 - 304

ishans were members of established sacred lineages (often with the additional title of khoja), ${ }^{11}$ others might be of humbler origin but acquire influence through personal charisma or through being the disciple of an important religious teacher. ${ }^{12}$ The Dukchi Ishan fell into the latter category: he had been the pupil of a prominent NaqshbandiyyaMujadidiyya sheikh, Ishan Sultankhan Tura, whose authority he appears to have inherited on the latter's death in 1882. In 1886 he performed the hajj to Mecca, and on his return established a religious community in his home village of Ming-Tepe near Andijan, where he became renowned both for his miracles and his charity, feeding hundreds of followers and gaining recognition from local (tuzemnyi or 'native') officials. ${ }^{13}$ Whilst one must always beware of the artificial division between 'popular' and 'official' Islam which is a product of the Sovietological tradition, it seems clear that the educated 'ulama of Turkestan were largely condemnatory of the Dukchi Ishan and his followers, possibly because of his humble background: he was, for instance, roundly condemned by the Bukharan historian Sami as a charlatan preying upon the credulity of the people of Ferghana. ${ }^{14}$ In general Muslim intellectuals, many of whom served the Russian regime as qazis and in other capacities and had a good understanding of the extent of Russian military power, were opposed to armed struggle against a regime which still preserved what they saw as the essential attributes of Islam. ${ }^{15}$ The Dukchi Ishan is thus often seen as a popular leader, and someone who to some extent stood outside the established structures of religious authority in Turkestan. ${ }^{16}$

Interpretations of the his motives and those of his followers also vary: Beatrice Manz has suggested that the Andijan uprising should be understood primarily as a tribal movement amongst the nomadic Qipchaqs of Eastern Ferghana to regain the political ascendancy they had once known in the 1840s and 50s when they controlled the Kokand

\footnotetext{
11 Or more correctly khwaja: this term is more or less synonymous with sayyid, i.e. claiming descent from the Prophet's kin. However, khojas derived their authority and influence in large part from belonging to local Sufi lineages within the three principal Central Asian brotherhoods: the Naqshbandiyya, Yasaviyya and Kubraviyya. See A. A. Khismatulin 'Khwajagan' Islam na territorii byvshei Rossiiskoi Imperii..[slam on the territory of the former Russian Empire] Vol.I pp.417-425; Devin DeWeese 'The Masha'ikh-i Turk and the Khojagan' Journal of Islamic Studies 7/2 (1996) pp.180-207

12 Sergei Abashin 'Ishan' Islam na territorii byvshei Rossiiskoi Imperii Vol.I pp.164-6

${ }^{13}$ Komatsu 'The Andijan Uprising Reconsidered' pp.30-37

${ }^{14}$ Babajanov 'Dukchi Ishan und der Aufstand' pp.185-6; Mirza 'Abd al-'Azim Sami Ta'rikh-i Salatin-i Manghitiia. Istoriya Mangitskikh gosudarei pravivshikh v stolitse, blagorodnoi Bukhare [Ta'rikh-i Salatin-i Manghitiyya. The history of the Manghit sovereigns ruling in the capital, Bukhara the blessed] ed. \& trans. L. M. Epifanova (Moscow, 1962) text ff121b-122a trans. pp.123-4; Aftandil Erkinov has also demonstrated that almost all of the verses composed by Turkestani intellectuals about the Andijan Uprising condemned the ishan, or even suggested that he was a heretical Shia Irani in origin. Erkinov 'Andizhanskoe vosstanie' pp.111-137

${ }^{15}$ Hisao Komatsu 'Dar al-Islam under Russian Rule as understood by Turkestani Muslim Intellectuals' in Tomohiko Uyama (ed.) Empire, Islam, and Politics in Central Eurasia (Sapporo, 2007) pp.10-17

${ }^{16}$ Babajanov 'Andizhanskoe vosstanie 1898 goda i “musul'manskii vopros" v Turkestane' pp.177-8
} 
'Sufism, Panislamism and Information Panic: Nil Sergeevich Lykoshin and the aftermath of the Andijan Uprising' Past \& Present No.214 (2012) pp.255 - 304

Khanate. ${ }^{17}$ Bakhtiyar Babajanov argues that the Dukchi Ishan was pushed rather reluctantly into leading an armed revolt against the Russians, and that whilst his priorities were certainly religious and moral, those of some of his followers may have been political and economic. ${ }^{18}$ Hisao Komatsu emphasises that he saw himself as a purifier of the Muslim community, and that by 1895-6 he had become convinced of the need for jihad against the Russians in order to protect and renew religion and halt what he saw as the moral decay brought about by their rule. ${ }^{19}$

Whilst this article will hopefully make some contribution to the ongoing debate about the nature of the Andijan Uprising, that is something better left to trained orientalists who are proficient in Central Asian languages. My central purpose is instead much closer to that of Galuzo in 1926, reflecting a shared source-base made up largely of Russian official documents. What is striking about Galuzo's early account of Andijan is his focus on the effect of the uprising in generating paranoia within the colonial regime, as revealed in the archives of the chancellery of the Turkestan Governor-General with which he worked. At the time the Andijan events seemed to confirm Russian assumptions about the inherently 'fanatical' nature of Turkestan's Muslims, and the consequent dangers of an Islamic revolt and holy war, or ghazavat. Many officials also believed that the revolt was evidence of a new, pan-Islamic threat, citing the lengthy period the Dukchi Ishan had spent at Mecca and Medina whilst on pilgrimage, and, more sinisterly, the possibility that he had been in direct communication with the Ottoman Sultan Abdülhamid II, or with Turkish and Afghan agents. ${ }^{20}$ Andijan called into question the whole policy of 'ignoring' Islam (ignorirovanie) which had been pursued by the Russian state in Turkestan since the appointment of the first Governor-General of the region, Konstantin Petrovich von Kaufman, in 1867. It led the then Governor-General, Dukhovskoi, to advocate a more interventionist approach towards Islam, and its long-term impact on the colonial administration in Turkestan was profound. ${ }^{21}$

\footnotetext{
${ }^{17}$ Beatrice Forbes Manz 'Central Asian Uprisings in the Nineteenth Century: Ferghana under the Russians' Russian Review 46/3 (1987) pp.269-71

${ }^{18}$ Babajanov 'Dukchi Ishan und der Aufstand' p.183; 'Dukchi Ishan i Andizhanskoe Vosstanie' p.263

${ }^{19}$ Komatsu 'Dar al-Islam' pp.13-14

${ }^{20}$ Sal'kov "Andizhanskoe vosstanie" p.39; this was a response to the revival or resacralisation of the caliphate by Abdülhamid II as both an internal and international focus of Islamic loyalty, but these fears of divided Muslim loyalties appear to have been mirrored in the Ottoman ruling elite's attitude to Sunni Muslims under Russian rule: Selim Deringil The Well-Protected Domains. Ideology and the Legitimation of Power in the Ottoman Empire (London, 1999) pp.46-7, 54-5

${ }^{21}$ S. M. Dukhovskoi 'Vsepoddanneishii doklad Turkestanskogo general-gubernatora general ot infanterii Dukhovskogo "Islam v Turkestane”, ['General Report of the Turkestan Governor-General Infantry General Dukhovskoi “Islam in Turkestan" '] (Tashkent, 1899) reprinted in D. Yu Arapov (ed.) Imperatorskaya Rossiya i musul'manskii mir [Imperial Russia and the Muslim world] (Moscow, 2006) pp.142-63; Komatsu 'The Andijan uprising reconsidered' pp.47-8
} 
'Sufism, Panislamism and Information Panic: Nil Sergeevich Lykoshin and the aftermath of the Andijan Uprising' Past \& Present No.214 (2012) pp.255 - 304

Whilst the official reaction to Andijan has been considered at the level of relations between Tashkent and St Petersburg, the grassroots impact on the colonial administration has barely been considered since Galuzo's brief account. ${ }^{22}$ The present article seeks to explore this phenomenon through the analysis of a hitherto-unknown incident which took place over a period of a year and a half, beginning just a few months after the Andijan Uprising. The setting is an area between the towns of Chimkent and Aulie-Ata (modern-day Shymkent and Taraz), hundreds of miles from Andijan on the southern fringes of the steppe in what is now Kazakhstan, and was then called Syr-Darya province. This was a liminal region where the worlds of settled town-dwellers (or 'Sarts'), ${ }^{23}$ Kazakh steppe nomads and mountain Kyrgyz intersected, characterised by a mixture of nomadic pastureland, irrigated agriculture (along the Syr-Darya and the river Arys) and mountains (the Kara-tau and Buraldaev ranges). From the early $19^{\text {th }}$ century until the Russian conquest in 1864 it had formed part of the Khanate of Kokand, the youngest of Central Asia's states, whose power-base was in the Ferghana Valley but which sought to project its influence deep into the steppe. ${ }^{24}$ After the conquest, like the rest of Russian Turkestan, it was placed under a thinly-spread military administration which relied heavily on local intermediaries, most notably the volostnoi upravitel' (canton administrator or mingbashi in Turkic) and qari (Islamic judge). ${ }^{25}$ By the 1890 s it was one of the few regions in Turkestan which had seen significant levels of Russian peasant settlement, adding further to an already complex social mix.

\footnotetext{
22 Babajanov in 'Andizhanskoe vosstanie 1898 goda i “musul'manskii vopros” v Turkestane' pp.166-177 deals with some of the rhetorical responses to Andijan, but not its practical consequences for the local administration; Elena Campbell meanwhile concentrates on high-level debates in St Petersburg and does not consider the attitudes of the military who actually governed most of the empire's Muslims. See 'The Muslim Question in Late Imperial Russia' in Burbank, von Hagen \& Remnev (ed.) Russian Empire. Space, People, Power 1700-1930 (Bloomington, IN, 2007) pp.325-6

${ }^{23}$ A much-debated term, which when used by nomads indicated a sedentary peasant or town-dweller. See V. V. Barthold 'Sart' Ency. of Islam Vol.IV S-Z (Leiden \& London, 1934) pp.175-6

${ }^{24}$ Kokand ruled over Chimkent from ca.1810 and Aulie-Ata from ca.1826 until 1864, when both towns were taken by the Russians. The Khanate was finally annexed altogether in 1875-6. On the emergence of the Khanate in the mid-18 ${ }^{\text {th }}$ century see Scott Levi 'The Ferghana Valley at the Crossroads of World History: the rise of Khoqand 1709-1822' Journal of Global History 2/2 (2007) pp.213-232. On Kokandi administration in the southern steppe see T. K. Beisembiev 'Vysshaya administratsiya Tashkenta i yuga Kazakhstana v period Kokandskogo Khanstva: 1809-1865gg' ['The higher administration of Tashkent and southern Kazakhstan during the period of the Kokand Khanate: 1809-1865'] Istoriko-kul'turnye vaaimosyyazi Irana i Dasht-i Kipchaka v XIII - XVIIIvv [The historico-cultural relations of Iran and the Dasht-i Qipchaq in the XIII - XVIII centuries] (Almaty, 2004) pp.291-313. On the earlier history of Aulie-Ata and Chimkent see A. I. Dobrosmyslov Goroda Syr-Dar'inskoi oblasti [Towns of Syr-Darya province]: Kazalinsk, Perovsk, Turkestan, Aulie-Ata i Chimkent. (St. Pb., 1912) pp.159-166, 182-190

$25 \mathrm{On}$ the system of administration in Turkestan (known as voenno-narodnoe upravlenie or 'military-popular administration' see A. S. Morrison Russian Rule in Samarkand 1868-1910. A Comparison with British India (Oxford, 2008) Chapters 4 \& 5.
} 
'Sufism, Panislamism and Information Panic: Nil Sergeevich Lykoshin and the aftermath of the Andijan Uprising' Past \& Present No.214 (2012) pp.255 - 304

The story is largely based on a single file from the Central State Archive of the Republic of Kazakhstan in Almaty, taken from the records of the local administration of Chimkent in 1898-1900. It is of interest not only because of the curious events which it describes, but also because of the identity of its principal compiler and protagonist, one Artillery Captain Nil Sergeevich Lykoshin, who was then serving as the assistant to the Military Commandant of the Chimkent district. Lykoshin (1860-1922) was a hereditary nobleman from Pskov who studied at the elite Pavlovskaya Military Academy before being commissioned into the artillery, but he never saw active military service. Instead he began an administrative career in Central Asia as a pristav (police-chief) in the small town of Ura-Tepe in 1889, before becoming the officer in charge of the 'Asiatic' quarter of Tashkent. The posting in Chimkent where we find him (and where he would remain until 1902) came in the early part of a glittering administrative career. Subsequently he became Commandant of the Khujand district from 1905 to 1912, head of the Amu-Darya Division from 1912-13, and he ended his career as a Major-General and Governor of Samarkand province from 1914-1917. ${ }^{26}$ Lykoshin had first given notice of his talents with a series of articles for Turkestanskiya Vedomosti (the Government newspaper) on life in the 'native' quarter of Tashkent. ${ }^{27}$ Since then he had translated the early Bukharan historian Narshakhi from Persian into Russian in collaboration with the great Russian orientalist Vasilii Barthold, and would later do the same with Muhammad Sadiq Kashghari's Code of Eastern Proprieties (first published in a handbook on Islam for administrators) on which he later based a book of instruction in Muslim social mores for his less refined compatriots. ${ }^{28}$ His output was a mixture of conventional orientalist scholarship (such as his translations of Narshakhi and the eighteenth-century Sufi poet Mashrab), ${ }^{29}$ semi-ethnographic work, ${ }^{30}$ writings on land-settlement, the functioning of the 'native' administration, and the

\footnotetext{
${ }^{26}$ M. K. Baskhanov Russkie Voennye Vostokovedy [Russian Military Orientalists] (Moscow, 2005) pp.145-7

${ }^{27}$ N. S. Lykoshin 'Pis'ma iz tuzemnogo Tashkenta' ['Letters from native Tashkent'] TV 12 th $-15^{\text {th }}$ February 1894 Nos.10-12

${ }^{28}$ N. S. Lykoshin (Trans.) 'Adab-ul'-Salikhyn. Kodeks prilichii na vostoke' ['Adab ul-Salikhin. Code of Proprieties in the East'] in V. P. Nalivkin (ed.) Sbornik materialov po musul'manstvu [Anthology of materials on Islam] (Tashkent, 1900) Vol.II pp.23-86; "Khoroshii ton” na vostoke. [“A good tone in the East"] (St Pb., 1915); Interestingly the copies of his works in the library of the Oriental Institute of St Petersburg all bear autographs indicating that they were presented by him to the great Russian orientalist V. V. Barthold. ${ }^{29}$ N. S. Lykoshin (trans.) \& V. V. Bartol'd (ed.) Istoriya Bukhary Mukhameda Narshakhi [Muhammad Narshakhi's History of Bukhara] (Tashkent, 1897); Divana-i-Mashrab. Zhizneopisanie populyarneishago predstavitelya mistitsizma $v$ Turkestanskom Krae [Diwana-i Mashrab. A description of the life of the most popular representative of mysticism in the Turkestan region] (Samarkand, 1911); Muradbek i Fatima (Khivinskoe Predanie) [Muradbek and Fatima. A Khivan Legend](Tashkent, 1896)

${ }^{30}$ N. S. Lykoshin O gadanii u sredneaziatskikh turemtsev [On divination amongst Central Asian natives] (Samarkand, 1908)
} 
'Sufism, Panislamism and Information Panic: Nil Sergeevich Lykoshin and the aftermath of the Andijan Uprising' Past \& Present No.214 (2012) pp.255 - 304

progress of 'civilization' amongst the natives. ${ }^{31}$ To these full-length books he added a steady stream of articles on the history, language and ethnography of Central Asia for Turkestanskiya Vedomosti, its unofficial counterparts, Russkii Turkestan and Turkestanskii Kur'er, and even, briefly, in the aftermath of the 1905 revolution, the Socialist newspaper Samarkand. Lykoshin is perhaps the most prominent example of the very common overlap to be found between the production of scholarly work on Russia's colonial territories and their administration. ${ }^{32}$ Hitherto we have known much more about his academic than his administrative career, and this article also aims to flesh out the biography of one of the most important figures of pre-revolutionary Turkestan. His responses both to the Andijan uprising itself and to the story which he subsequently found himself investigating within his local fief offer a fascinating opportunity to examine the inter-relation between orientalist knowledge and colonial power at the local level.

The Russian reaction to Andijan is an excellent example of what C. A. Bayly has called an 'information panic', where in the absence of reliable intelligence the agents of the colonial state tied themselves in knots running after orientalist will-o'the-wisps which were in large part a product of their own prejudices against the subject population. ${ }^{33}$ In India the best-known case is probably that of Thuggee, the supposed all-India murder cult 'discovered' and 'suppressed' by William Sleeman, who was himself largely responsible for weaving real but diverse cases of banditry and highway robbery across central India into a single, coherent religious conspiracy. ${ }^{34}$ In that case initial fear and paranoia were succeeded by complacency as the colonial authorities congratulated themselves on a job well done. Growing British racial and cultural prejudice against Indians in the 1830s and 40s meant that older native sources of intelligence were treated with increasing contempt, and this information failure helped ensure that the outbreak of open rebellion in 1857 took the British almost completely by surprise. ${ }^{35}$ Fifty years later in 1907 an outbreak of terrorism in Bengal also saw the colonial state in India succumb to paranoia and neuroses, as the police saw subversive threats lurking in every student gathering, in vernacular translations of articles from the British press which were critical of the Government of India, or indeed smears of mud on mango trees; however, out of 1,038 who were arrested

\footnotetext{
${ }^{31}$ N. S. Lykoshin Rezul'taty sblizheniya russkikh s turemtsami [Results of the rapprochement of Russians with natives] (Tashkent[?], 1903); Chapkullukskaya volost' Khodzhentskogo uezda Samarkandskoi oblasti [Chapkulluk canton of the Khujand district of Samarkand province] (Samarkand, 1905)

32 Alexander Morrison “ "Applied Orientalism” in British India and Tsarist Turkestan' Comparative Studies in Society \& History 51/3 (July 2009) pp.619-47

${ }^{33}$ C. A. Bayly Empire and Information (Cambridge, 1996) pp.149, 171-3

${ }^{34}$ Kim Wagner Thuggee. Banditry and the British in Early Nineteenth-Century India (Basingstoke, 2007) pp.1-12, 217-226

${ }^{35}$ Bayly Empire and Information pp.365-76
} 
'Sufism, Panislamism and Information Panic: Nil Sergeevich Lykoshin and the aftermath of the Andijan Uprising' Past \& Present No.214 (2012) pp.255 - 304

for suspected sedition, only eighty-four were actually prosecuted. ${ }^{36}$ Whilst these panics could obviously have unpleasant consequences for some, in general they were a drain on the resources of the colonial state, distracting its police and intelligence services from more important or dangerous matters, and taking up an extraordinary amount of administrative time. Not only are they interesting in themselves, they often reveal the deepest preoccupations and fears of colonial rulers, and the limits to the control they could exercise over the societies they had conquered.

Threatening or disturbing rumours always have the capacity to generate a disproportionate and ill-directed state response, but as Ann Stoler has shown, this effect is enormously magnified in a colonial context where the state is undermanned and has a very limited understanding of the society it is trying to control. The colonial state's handicap is shared by the historian who uses the paperwork it produced, and the construction of clear narratives from colonial sources of the kind presented in this article is highly problematic. Rumour, prejudice and ignorance combine to ensure that past events are seen through a murky fog, if at all. ${ }^{37}$ In the case of this account, when we hear voices from non-Russian protagonists they are filtered through petitions submitted to the authorities or witness-statements taken down by Russian officials, often using an interpreter. However, these accounts, and the rumours they relate, are worthy of investigation in themselves. This is partly because fear and confusion were so often the mainsprings of official thought and action, but also because, despite their imperfections, these sources can still tell us a good deal about popular understandings both of the Dukchi Ishan and his legacy, and of Russian attitudes towards them. Any conclusions drawn from this sort of material must remain speculative, but sometimes even the 'archives of repression' - interrogations, sworn depositions and witness statements - can help us recover elements of a history from below. ${ }^{38}$

\footnotetext{
${ }^{36}$ D. K. Lahiri Choudhury 'Sinews of Panic and the Nerves of Empire. The Imagined State's Entanglement with Information Panic, India c.1880 - 1912' Modern Asian Studies 38/4 (2004) pp.978-82, 997

${ }^{37}$ Ann Stoler " "In Cold Blood": Hierarchies of Credibility and the Politics of Colonial Narratives' Representations 37 (Winter, 1992) pp.179-182

38 The value of this approach in understanding popular culture on its own terms - using the records of the Inquisition - was famously demonstrated by Emmanuel LeRoy Ladurie in Montaillou: Cathars and Catholics in a French village, 1294-1324 (London, 1978) and by Carlo Ginzburg in The Cheese and the Worms. The Cosmos of a Sixteenth-Century Miller (Baltimore, MD, 1980). Naturally there are difficulties with using interrogations in this way, but they are sometimes the only record which survives of certain subaltern voices, however filtered and distant they may be. See further David Arnold 'Rebellious Hillmen: The Gudem-Rampa Risings 1839-1924' Subaltern Studies I (Delhi, 1982) pp.88-142 which successfully rediscovers a history of subaltern resistance to colonial rule using almost exclusively colonial sources.
} 
'Sufism, Panislamism and Information Panic: Nil Sergeevich Lykoshin and the aftermath of the Andijan Uprising' Past \& Present No.214 (2012) pp.255 - 304

\section{I: The ishan is alive}

On the $17^{\text {th }}$ August 1898, three months after the Dukchi Ishan had led his followers in that ill-fated attack on the Russian garrison of Andijan, a 'Kirgiz' (i.e. a Kazakh) ${ }^{39}$ called Mambet Kalkabekov from No.11 aul (temporary nomadic settlement), Kuyuk volost' (canton), in the Aulie-Ata district of Syr-Darya province, approached State Counsellor A. Il'inskii, who was then on a tour of inspection, with a peculiar story calculated to set alarm bells ringing with a vengeance in the colonial administration..$^{40}$ Kalkabekov claimed that up to 300 firearms had been distributed amongst the Kazakhs of the Aulie-Ata district by the Dukchi Ishan in preparation for another uprising, a story he would still be repeating the following year, by which time it had thrown the colonial administration into turmoil:

'Disregarding the justice of his Majesty the Emperor, the foolish Kirgiz [sic] have duped themselves into believing that the ishan, as an emissary of God, is alive. ${ }^{41}$

Muhammad Ali Sabyr had been executed by the colonial authorities on $12^{\text {th }}$ June after a summary trial, but the attack which he led was destined to have a long afterlife in the Russian official mind. In this atmosphere of heightened paranoia, the strange story which this Kazakh informant now unfolded seemed all too plausible. Speaking to Il'inskii through an interpreter, Kalkabekov claimed that his father-in-law, a wealthy man called Avalbek Tileuliev Umarkul, was at the heart of the conspiracy.

'Four years ago he received from somewhere or other two firearms and began to learn how to shoot. His wife Tolkun often laughed at him and said to him: "you've gone crazy, why are you learning to shoot at your age?" To this he replied, "It's a good business, this is what the ishan commanded when he sent me these weapons." I did not know and did not ask from which particular ishan and for what purpose he had obtained the weapons. In autumn last year Avalbek began to relate to his family, of which I was a part, that in the Andijan district, in the village of Ming-Tepe, lived Diwana-Ishan Muhammad Ali Sabyrov, a holy man, to whom had fallen from heaven some holy book or other: that he performed miracles, for instance cooking food in a kazan [cauldron] without fire; that in this book it was written, that anyone who helps the ishan in his holy affairs, he will be delivered from the sword, sabre and all unhappiness; because of this Avalbek sometimes advised me to learn how to shoot.' ${ }^{42}$

\footnotetext{
${ }^{39}$ In the $19^{\text {th }}$ century the Russians invariably referred to Kazakhs as 'Kirgiz', in order to distinguish them from their own Cossacks (Kazaki). The modern-day Kyrgyz were referred to as 'Kara-Kirgiz'. For the purpose of this article I will leave the original terminology in quotations, but use the correct terms in the text.

40 Tsentral'nyi Gosudarstvennyi Arkhiv Respubliki Kazakhstan [Central State Archive of the Republic of Kazakhstan] (TsGARKaz) Fond (F.) 124 'Chimkentskoe uezdnoe upravlenie' ['Chimkent district administration'] Opis' (Op.) 1 Delo (D.) 7 'Materialy doznaniya po voprosu tainogo snabzheniya oruzhiem naseleniya ishanom Kh. Abdurakhmanovym' [Materials from the inquiry on the question of the secret supplying of the population with weapons by the ishan (and) Habibullah Abdurrahman] Protokol [Minutes] 17/08/1898 11. [ff.] 24-5ob [verso]

${ }^{41}$ TsGARKaz F.124 Op.1 D.7 translation of a petition from Mambet Kalkabekov to the Military Governor of Syr-Darya Province 15/06/1899 1.8

42 TsGARKaz F.124 Op.1 D.7 Protokol 17/08/1898 1.24; these stories of the Ishan's miracles are paralleled in the Manaqib-i Dukechi Ishan trans. pp.163-4
} 
'Sufism, Panislamism and Information Panic: Nil Sergeevich Lykoshin and the aftermath of the Andijan Uprising' Past \& Present No.214 (2012) pp.255 - 304

Kalkabekov went on to describe how one Tugulbai, some 'unknown, passportless native, Sart or Kirgiz I don't know' was living with Avalbek, and that the old man had frequently sent him to Andijan to attend upon the Dukchi Ishan. Avalbek had only failed to participate in the uprising himself, so Kalkabekov claimed, because his gun exploded whilst he was out hunting, injuring one of his eyes, and he had urged Kalkabekov to join the ishan's forces in his stead. Kalkabekov said that he had refused, replying 'that under the rule of Kokand we were oppressed, and now under the rule of the Russian Tsar we live well, peacefully.' One night about four months previously, Kalkabekov continued, Tugulbai had ridden in from Andijan, and, thinking that Kalkabekov was asleep, told Avalbek that the ishan was sending weapons through the high passes from the Ferghana Valley so as to avoid detection, and that they were to be distributed among the willing. Kalkabekov claimed to have seen the weapons with his own eyes, six large heaps of them wrapped up in felt, with at least fifty to a hundred firearms in each. Finally, when his father-in-law found he could not persuade him to join the ishan, he became enraged, drove him from the house and took from him his wife and three-year-old son, leaving Kalkabekov to look after his remaining one-year-old son alone. ${ }^{43}$ He told Il'insky:

'If you ask the Kirgiz about this matter then they, of course, say that I am an idiot and tell lies. I have been afraid to go to the uyezdnyi nachal'nik [district commandant] up until now, afraid that he would shout at me and turn me out, and then send Djigits [mounted bodyguards] to ask the canton administrators if I have been telling the truth, and that they would speak against me. Learning that you had been sent here by higher authority, I hurried to you to tell you about what is written above. I am very afraid that the Kirgiz of Kuyuk canton will kill me for giving this information.' ${ }^{34}$

He asked to be sent away to his relatives in the Kopal district, far to the north-east in Semirechie. Il'inskii took his testimony entirely seriously, writing that

'Mambet Kalkabekov gave his evidence clearly: he answered all questions quickly, without any stumbling. He gave the impression that he was telling the truth, and not lies. His account is clearly entirely truthful. ${ }^{35}$

When the local police chief was sent to Avalbek's aul to investigate the allegations, he claimed that the local Kazakhs replied cagily to his questions and refused to indicate where Avalbek lived. When he eventually found him he discovered that the old man was indeed lying in bed, suffering from an eye injury caused when his gun exploded. He claimed never to have heard of the Dukchi Ishan or to know what his name was or where

${ }^{43}$ TsGARKaz F.124 Op.1 D.7 Protokol 18/08/1898 11.24ob - 25

${ }^{44}$ Ibid 1.25

45 Ibid $1.25 \mathrm{ob}$ 
'Sufism, Panislamism and Information Panic: Nil Sergeevich Lykoshin and the aftermath of the Andijan Uprising' Past \& Present No.214 (2012) pp.255 - 304

he lived. There the police chief also found Avalbek's daughter, Mambet Kalkabekov's wife Usmunkul, who explained the matter to him thus:

'Her husband, Mambet, had recently abandoned his work and taken to petty thievery. They lived in a separate yurt. In order to get enough milk for their children they were forced to turn to their neighbours, as her husband would waste whole days without any concern for the feeding of his family. Finally she decided to dump her husband and return to her father, which greatly enraged Mambet who even threatened to kill her if she did not return to him.' ${ }^{46}$

The police chief then had all the yurts of the aul searched, turning up a store of gunpowder and a few firearms, which he confiscated although the owners insisted they only used them for hunting. Noting that Avalbek's family called down imprecations on Mambet Kalkabekov's head for having brought the Russians upon them, he concluded that

'Mambet's deposition is the result of his relations with his father-in-law, but the inconsistency of those people interrogated and the findings given above suggest that there is truth in Mambet's account, all the more so because it would be difficult to come up with such a statement without any facts at all. ${ }^{47}$

Lt-Col. Usov, the Aulie-Ata district Commandant, had by now informed Tashkent of the matter, and the prokurator (State Prosecutor) of the Tashkent okrushnyi sud (regional court), N. N. Michurin, demanded further enquiries. He ordered the Commandant to send search parties to scour the hilly territory of the Aulie-Ata district for weapons; the latter reported a year later that they had discovered sixty firearms in the possession of Kazakhs, although the owners all insisted that they had inherited or purchased them rather than receiving them from the ishan, and that they used them for hunting and selfdefence. The Commandant remarked that the search had been conducted by former members of the native administration, together with some Kazakhs employed for the purpose, and he was not convinced that it had been particularly thorough, in view of 'the bias amongst these natives towards their co-religionists, and the lack of sufficient goodwill amongst the Kirgiz', together with the fact that he simply did not have the resources to conduct a house-to-house search in a district with a population of 280,000 souls. $^{48}$

The other part of the investigation consisted of taking down doznanie (sworn depositions) from those involved. This proved a lengthy task, as Kalkabekov did not remain idle: between the $22^{\text {nd }}$ August and the $4^{\text {th }}$ December 1898 he approached the Aulie-Ata District Commandant eight times, each time giving either a slightly different version of his original story or else an entirely new one accusing other Kazakhs of being

46 Ibid Doznanie [witness statement] 19/08/1898 1.26ob

47 Ibid Protokol 25/08/1898 1.28

48 Ibid Aulie-Ata District Commandant (D. C.) to the Tashkent Prokurator 24/06/1899 11.14-ob 
'Sufism, Panislamism and Information Panic: Nil Sergeevich Lykoshin and the aftermath of the Andijan Uprising' Past \& Present No.214 (2012) pp.255 - 304

followers of the Dukchi Ishan and of being involved in Islamic conspiracy. The Commandant then travelled out to the auls of those accused to conduct interrogations, which invariably produced nothing but denials of all knowledge of the ishan or of ever having been to the Ferghana valley. On the $25^{\text {th }}$ August Kalkabekov alleged that in the aul of Meke-Kamal in the neighbouring Chimkent district an elderly Kazakh called Dikambai Batov was a follower of the ishan, and that his two sons, Mamyr and Shukur, had travelled to Ferghana to see him and returned with weapons. The brothers denied all knowledge of this, and a search of the aul failed to yield any weapons at all. Local officials (including Khan Khoja Turgunbaev, the local $b i{ }^{49}{ }^{49}$ when questioned said that neither had left their aul all year. Instead they accused Kalkabekov of inventing the story to distract attention away from his stealing of cattle from the neighbouring Russian settlement of Vysokoe. ${ }^{50}$ This accusation was never followed up, despite, or perhaps because it came from members of the colonial regime's own 'Native Administration', and Kalkabekov continued to approach the district authorities with new stories roughly every two weeks, each of which was then investigated. Occasionally one of his denunciations would result in the confiscation of one or two unlicensed firearms, and at other times Kalkabekov brought these in himself, claiming to have wrested them from their owners. ${ }^{51}$ He might have become a useful stool-pigeon, but none of the time-consuming investigations into his allegations of a widespread Islamic conspiracy had produced one shred of evidence to back them up.

After ten months of fruitless investigations, on the $5^{\text {th }}$ May 1899 Kalkabekov approached the assistant to the Commandant of the Chimkent district, Artillery Captain Nil Sergeevich Lykoshin, and asked to have a word in secret. He repeated his claim that the Dukchi Ishan had distributed 300 weapons throughout the Aulie-Ata district, and this time alleged that twenty-nine of them could be found in the yurt of a Kazakh called Kembai Turakildiev. When Lykoshin suggested that Kalkabekov might like to accompany him on an expedition to seize the weapons, he suddenly changed his story, saying that the weapons would no longer be there. He begged Lykoshin to let him go and to give him a postcard with his address so that he could send him more accurate information about the location of the weapons without having to leave his aul. Lykoshin agreed and gave him

\footnotetext{
49 A judge, administering Kazakh customary law or 'adat.

50 TsGARKaz F.124 Op.1 D.7 Protokol 25/08/1898 1.29; Vysokoe was one of the oldest Russian settlements in the region, founded in 1889, and one of the most prosperous: already in 1893 it had 130 houses strung out along four versts of the post-road between Chimkent and Aulie-Ata. I. Geier Po russkim seleniyam SyrDar'inskoi oblasti (pis'ma s dorogi) [Amongst the Russian settlements of Syr-Darya Province (letters from the road)] Vol. 1 Chimkentskii uezd [Chimkent district] (Tashkent, 1893) pp.132-3

${ }^{51}$ Ibid Protokoly 24/09/1898, 15/10/1898, 26/10/1898, 30/10/1898, 15/11/1898, 4/12/1898 11.30-32
} 
'Sufism, Panislamism and Information Panic: Nil Sergeevich Lykoshin and the aftermath of the Andijan Uprising' Past \& Present No.214 (2012) pp.255 - 304

one, and then, as he put it 'without any prompting on my part', Kalkabekov began to tell him that, apart from the weapons cache, he also knew of the whereabouts of an emissary from the Amir of Afghanistan in the Tashkent district. Lykoshin asked him to write down what he knew and address it to the Military Governor of Syr-Darya province, which Kalkabekov did, producing a one-page document in Turki which said that the Afghan Amir had despatched four emissaries, led by one Mullah Turab, and that he had already informed several members of the native administration of this without getting any response. ${ }^{52}$ After some further interrogation Lykoshin gave him twenty-five kopeks and let him go. In stark contrast to all the other officials who had spoken to him up to that point, Lykoshin was highly sceptical about Mambet Kalkabekov's story:

'Having detained Mambet, I informed the commandant of the district that I had received a report from man who was clearly not entirely sane [ot cheloveka povidimomu ne vpol'no normal'nogo], in as much as Mambet did not speak clearly, did not explain in detail, spoke at times about unrelated subjects, and himself admitted that the Kirgiz consider him to be insane. ${ }^{53}$

It was perhaps an awareness that Lykoshin had not taken him particularly seriously which led Kalkabekov to submit another lengthy petition (in his own, sprawling hand) to the Governor of Syr-Darya province on $15^{\text {th }}$ June 1899, in which he repeated many of his earlier allegations about the belief amongst the Kazakhs that the ishan was alive, and organising an uprising against the Russians, throwing in an additional charge of assault against the administrator of the Mailikent canton. Curiously, however, he did not mention his further allegations about the emissaries of the Amir of Afghanistan. ${ }^{54}$

\section{II: The Spectre of Pan-Islamism}

The plot thickened further when on $3^{\text {rd }}$ July 1899 Lykoshin and the Prosecutor of the Tashkent regional court, N. N. Michurin, travelled to the Russian settlement of Vysokoe near Chimkent (allegedly the location of Kalkabekov's cattle-raiding) to investigate a mysterious letter which had been found there. The starosta (village elder), Lev Terekhov, told them that two peasants called Akim Solovyanov and Maksim Balaukii, who had been visiting the neighbouring Kazakh settlement of Chakpak, (which was the aul of Kalkabekov's father-in-law, Avalbek Tileuliev) to buy koumiss (fermented mare's milk), had spotted a Kazakh boy going from yurt to yurt with a piece of paper. They had taken it from him, intending to use it to make cigarettes, but then noticed that it bore

52 Ibid Mambet Kalkabekov to the Military Governor of Syr-Darya Province 05/05/1899 11.21-ob

53 Ibid Protokol 07/05/1899 11.22-ob

54 Ibid translation of a petition from Mambet Kalkabekov to the Military Governor of Syr-Darya Province 15/06/1899 11.7-8; However the translator has added a note saying that some parts of the original Turki text of the petition (11.9-11ob of the file) 'owing to the lack of clarity and low literacy of Mambet could not be translated'. 
'Sufism, Panislamism and Information Panic: Nil Sergeevich Lykoshin and the aftermath of the Andijan Uprising' Past \& Present No.214 (2012) pp.255 - 304

writing and a seal, and thought it might be connected to rumours of a Kazakh revolt. ${ }^{55}$ On their way back to the village, they bumped into the omnipresent Mambet Kalkabekov, to whom they gave the letter as he was literate, and who told them (in Russian, so they claimed) 'the Kirgiz are organising to slaughter you Russians, and the first among them is Avalbek'. Kalkabekov had then told one of them that the Kazakhs had obtained over 1,000 firearms, although when challenged he claimed to have mentioned just one: the starosta immediately sent in a lengthy report to the district authorities, prompting the visit from Lykoshin and the Prosecutor. ${ }^{56}$ When the first peasant was questioned directly, he stated that, contrary to the account of the starosta, they had not taken the letter from a Kazakh boy but had been given it by Kalkabekov himself, but the other man gave a different version, testifying that a young Kazakh boy had come up to them in the aul and that when his companion had asked 'kaghaz bar?' ('is there paper?') he had given him the letter; he also said that Kalkabekov had read out the letter to them aloud 'po sartovskii' (in 'Sart') but had not translated it, simply telling them to take it to the starosta. ${ }^{57}$ The inconsistency in these accounts was explained when the village elder's eight-year old daughter, Anna L'vovna Terekhova, gave remarkably composed testimony which must have caused her parents no little embarrassment:

'I know this Mambet by sight, he has sometimes been a guest in our house, but I have not heard from my father whether he has been a guest of Mambet. When he handed over the letter Akim explained, that it told of the preparations of the Kirgiz to kill Russians. Mother and I when we heard these words were scared and cried out. On that same day we sent for Mambet, he came and in front of me, father, mother, and grandmother admitted that he gave the letter to Akim and asked that they tell no-one that they received the letter from him, but say instead they received it from some Kirgiz boys. At this Mambet gave father lots of paper money, which father, Akim Solovyanov, Maxim Balaukii and the clerk Daniil Bezdetkov divided amongst themselves, and in the evening in our house many people drank vodka.

Her mother tried to undo the damage by saying that 'the account given by my daughter is entirely untrue, and it is probable that because of her youth she was scared and told falsehoods', and Anna herself, presumably after her mother had had a word or two with her 'additionally said: I know nothing about the matter, and gave my first account because I was scared'. Although her father and the peasants also tried to contradict her account, it was with evident embarrassment and lack of conviction. ${ }^{58}$ The cat was out of the bag, and Lykoshin's summing-up of the interrogation made it quite clear that he had

\footnotetext{
${ }^{55}$ Ibid 11.2-4, Protokol 03/07/1899 1.40ob

${ }^{56}$ Ibid Protokol 3/07/1899 11.41-ob

${ }^{57}$ Ibid Protokol 03/07/1899 1l.44ob, 45ob

${ }^{58}$ Ibid Protokol 03/07/1899 11.46-7ob, 5/07/1899 1.53
} 
'Sufism, Panislamism and Information Panic: Nil Sergeevich Lykoshin and the aftermath of the Andijan Uprising' Past \& Present No.214 (2012) pp.255 - 304

already decided the letter originated with Kalkabekov himself. ${ }^{59}$ He accordingly set off at once for Kalkabekov's aul in Kuyuk canton, where he found the bird had already flown. Kalkabekov's mother, Symbat Kalkabekova, who was now married to her second husband, said that she had not seen him for some time: in May, she added the 'popular judge' (i.e. the bii) of the canton, Khan Khoja Turgunbaev, had turned up with a group of five Russian peasants from Vysokoe, including the starosta, and the latter had begun to beat Kalkabekov because he had told them that Turgunbaev knew the whereabouts of 1,000 weapons hidden amongst the Kazakhs of the district. She had paid them eight roubles to leave off hitting him, whereupon Kalkabekov went off to Aulie-Ata and she had not seen him since. Lykoshin then interrogated the bii, Turgunbaev, who said that the starosta of Vysokoe had approached him in May, asking him about an accusation by Kalkabekov that he was concealing the presence of weapons in the district. He had denied this, and suggested they go and ask Kalkabekov himself what he meant. When they arrived at the aul the Russian settlers had indeed attacked Kalkabekov and refused to leave off until they were paid (although he claimed that he had given them the eight roubles). Lykoshin searched Kalkabekov's yurt, but found nothing. ${ }^{60}$

Lykoshin's attention now turned to the mysterious letter itself, which became the object of extensive scrutiny. Written in what the Russians called the 'turemnyi' ('native') tongue, a rather generic Central Asian Turki, it purported to come from the Afghan Amir, whose name appeared both at the end of the text (as 'Habibullah Sultan'), and in the seal on the reverse (as Habibullah 'Abd al-Rahman Khan) ${ }^{61}$

'He is the Creator [Hwva al-bari]. Aval Bek Tilu oghli, Janzaq Sufi Bujaq oghli, and Ali Khwaja Ishan who are in charge of the territory of Chimkent and Aulie-Ata! I send this message to you. I sent tributes as recompense in reply to your letter of greeting which was brought here and read by Ahmad Ilgun oghli. I had four people whose leader was Mullah Turab meet another person who was under Aval Bek's command and ordered them "you should deliver the rifles and sabres sent by us to those who requested them, for the sake of Holy War [ghazat]." Habibullah Sultan. My Word [Sözum $]{ }^{, 62}$

Exhaustive enquiries as to the identity and whereabouts of Mullah Turab failed to yield any clues over the following months: he was rumoured to be in Samarkand, and Lykoshin wrote repeatedly to the Samarkand District Commandant asking if he had any

\footnotetext{
${ }^{59}$ Ibid Postanovlenie [Resolution] No.2 04/07/1899 1.48

${ }^{60}$ Ibid Protokol No.2, Protokol Osmotra [Minutes of inspection], 04/07/1899 1l.49-52ob

61 There is some confusion here: the Amir of Afghanistan at the time was 'Abd ur-Rahman Khan, who died in 1901. Habibullah was his son, but 'Abd ur-Rahman was often incapacitated by illness for the last years of his life, and Habibullah sometimes seems to have exercised some functions of Government.

${ }^{62}$ TsGARKaz F.124 Op.1 D.7 1.4ob. My thanks to Kimura Satoru of the University of Tokyo for this translation from the original, which differs in some respects from the Russian translation in the file.
} 
'Sufism, Panislamism and Information Panic: Nil Sergeevich Lykoshin and the aftermath of the Andijan Uprising' Past \& Present No.214 (2012) pp.255 - 304

news of him, but to no avail. ${ }^{63}$ Ahmad Ilgun oghli (Ilgunov) turned out to be a Kazakh from the Tashkent district who had spent some time in gaol, and someone (probably Michurin) found an old petition of his, together with a splenetic note regarding him from the District Commandant there, who described him as someone who "knowing how to write in Russian, is one of the most harmful to the people of all those in my district, occupying himself almost exclusively in writing petitions of a spurious nature. ${ }^{94}$ Lykoshin's subsequent enquiries as to his whereabouts revealed that he was in Smyrna in Ottoman Anatolia, something likely to fan suspicions of pan-Islamism. ${ }^{65}$ The other three names were all Kazakhs of the Chimkent district, and Lykoshin's next step was to interrogate them, beginning two days later with Kalkabekov's father-in-law, Avalbek, who simply repeated what he and his daughter had told the police chief a year before, saying that Kalkabekov had a grudge against him because of the failure of the marriage and a dispute over bride-price, and remarking on the shame which these inquiries had brought upon him and his daughter. ${ }^{66}$ The other two names were also apparently known to Lykoshin: one, Janzaq Bujaqov, was a judge in the neighbouring Buraldaev canton. The other, whom Lykoshin referred to as 'Afakhodzhinov', had been mentioned in Kalkabekov's petition of the $15^{\text {th }}$ June as someone who, together with his brother, Hal Khoja Afakhojinov, knew the whereabouts of the hidden weapons sent by the ishan. All three of these men, wrote Lykoshin, lived in the same area, between the Buraldaev mountains and the river Arys. In order that they could have no advance warning of his arrival, he rode there over the night of the $5^{\text {th }}-6^{\text {th }}$ July to carry out his investigations, but a search of their yurts yielded nothing. ${ }^{67}$ Two days later all three men were interrogated in Lykoshin's office in Chimkent, in the presence of Lykoshin himself, Michurin, and a translator. Janzaq Bujaqov, who was 61 years old and had served as administrator of the Buraldaev canton before he became a judge, said he did not recognise the seal, and denied knowing Mullah Turab, Ahmad Ilgunov or Avalbek. He said that he was certain this slander had been concocted by a powerful enemy of his, the former administrator of the neighbouring Mashat canton, Isa Batyrbekov, the son of Batyrbek dadkhwah, ${ }^{68}$ who had been an influential Kokandi official before the Russian conquest. Since his dismissal for

${ }^{63}$ Ibid Lykoshin to the Samarkand D.C. 26/08/1899 1l.142-ob; Samarkand D.C. to Lykoshin 20/10/1899

$11.127-o b$

${ }^{64}$ Ibid Tashkent D.C. 30/11/1898 11.35-6

${ }^{65}$ Ibid Telegram from Nikol'skii [?], Tashkent, to Lykoshin 08/07/1899 1.74

${ }^{66}$ Ibid Doznanie No.7 05/07/1899 11.61-ob

${ }^{67}$ Ibid Lykoshin Postanovlenie No.4 05/07/1899 11.61 ob-4

${ }^{68}$ Dadkhwah - literally a petitioner for justice, but in this case simply a middle-ranking court title. See T. K Beisembiev (ed.) The Life of 'Alimqul. A Chronicle of Nineteenth-Century Central Asia (London, 2003) p.18 n.9 
'Sufism, Panislamism and Information Panic: Nil Sergeevich Lykoshin and the aftermath of the Andijan Uprising' Past \& Present No.214 (2012) pp.255 - 304

corruption in 1887, he claimed, Isa and his son had occupied themselves with clandestine cattle-raiding, and lived almost permanently in Chimkent and the neighbouring sacred township of Sairam rather than in their aul. He then added:

'In Chimkent and Sairam there are such craftsmen as can prepare seals, and, according to rumour, Hal Khoja Afakhojinov is also mixed up in this together with Isa. ${ }^{69}$

Quite apart from its relevance to the question of the 'Afghan' letter, this revelation had clear criminal implications because forged seals in the names of former rulers and qazis were used in the preparation of fraudulent land titles and deeds of waqf which purported to date from before the conquest, and it was this aspect of Janzaq Bujaqov's testimony which particularly interested Lykoshin. Ali Khoja Afakhojinov, 50 years old and from the same aul, repeated Bujaqov's accusations against Isa Batyrbekov, saying that his younger brother, Hal Khoja, had got involved with the latter despite all his attempts to dissuade him, and that they were now enemies. Hal Khoja Afakhojinov, who was 45 and had spent some time in gaol, said that he had been approached some two months before by Mambet Kalkabekov, who claimed he had been despatched by the Russian administration to look for and collect weapons. He found none in his yurt, and went away, and Hal Khoja claimed not to have seen him since. On being asked who could have written the letter or produced the seal on it, he said 'Isa Batyrbekov used to occupy himself with similar things and ordered his seals from Mullah Muhammad Yusuf, living in Sairam, close to the mosque of Qazi Baizavi'. ${ }^{70}$

Lykoshin immediately sent his fellow-deputy, Staff-Captain Rukin, to search Isa Batyrbekov's yurt, whilst he himself hot-footed it to Sairam, just outside Chimkent. Here he first spoke to the canton administrator, who informed him that not long before Isa Batyrbekov and Hal Khoja Afakhojinov had been in Sairam together, asking where they could find the craftsman Mullah Muhammad Yusuf Muhammad Shukurov so that they

\footnotetext{
${ }^{69}$ Ibid Protokol No.5 8/07/1899 11.64ob-66

70 TsGARKaz F.124 Op.1 D.7 Protokol No.5 8/07/1899 11.66-67ob; In fact this document garbles the name of the mosque as 'Karol Baisavi', but in Shukurov's witness statement it is recorded more accurately. The mosque was destroyed during the Soviet period and the building now on the site (known as the mosque of Yusuf Sairami) was erected after 1991. It stands next to the mausoleum of Qazi Baizavi, who was described to me by Professor Mir Ahmad Mirhaldarov, author of Sairam Tarikhi (Chimkent, 1991) - the most recent Uzbek-language compilation of Sairam's sacred history - as a semi-legendary ruler of the region along the middle Syr-Darya in the $10^{\text {th }}$ century AD, probably identical with the Maulana Qutb al-Din 'Allama Baizavi mentioned by Devin DeWeese in 'Sacred History for a Central Asian Town: Saints, Shrines, and Legends of Origin in Histories of Sayrām, 18th-19th Centuries' Revue des mondes musulmans et de la Méditerranée Vols.89-90 (July 2000) http://remmm.revues.org/index283.html (accessed 21st January 2010) n.21. The guardian of the mausoleum said that it was also associated with a $19^{\text {th }}$-century qazi (she used the official Russian term 'narodnyi sud' or 'Popular Judge'), who was apparently a Chechen who had migrated to Sairam by way of Khorasan. My thanks to Professor Mirhaldarov for explaining the complex history of the building to me, and to Dr Beatrice Penati for questioning the guardian of the mausoleum, who spoke only Uzbek.
} 
'Sufism, Panislamism and Information Panic: Nil Sergeevich Lykoshin and the aftermath of the Andijan Uprising' Past \& Present No.214 (2012) pp.255 - 304

could get a seal cut. ${ }^{71}$ At the house of the latter, who was also the imam of the neighbouring mosque of Qazi Baizavi, Lykoshin at last found something to get his teeth into: Shukurov showed him the records he kept of all the seals he had cut, which consisted of slips of paper bearing their impressions, in an attempt to prove that he had never made anything resembling the purported seal of 'Abd al-Rahman Khan. However Lykoshin spotted a box, which Shukurov attempted to conceal, which on inspection turned out to contain 'seals of the former Muslim rulers.' It was taken away to Chimkent for inspection. On interrogation the seal-cutter referred to the great falling off in trade he had experienced after the Russians had introduced and enforced the use of governmentmade seals amongst the qazis and biis of Turkestan. ${ }^{72}$ Because of this, although he had initially refused Isa Batyrbekov's request to manufacture a seal for him in the name of Khudoyar Khan, the last ruler of Kokand, the offer of five silver roubles had proved too tempting. However, he flatly denied having made a seal in the name of 'Abd al-Rahman Khan, and said that those in the box Lykoshin had discovered were of no importance. ${ }^{73}$ The search of Isa Batyrbekov's yurt had meanwhile failed to yield anything of interest, and the man himself could not be found. He did not give his side of the story until the $4^{\text {th }}$ August, when he sent in a petition (typed, and in Russian, with only his signature in the Arabic script at the end, showing that he was an old hand at this sort of thing). In this he wrote that he had been administrator of the Mashat canton for 23 years, had received numerous medals and decorations (he made a point of writing that one of these had been awarded directly by the Tsar) ${ }^{74}$ and that he had been greatly upset to find that his yurt had been searched during his absence, bringing shame upon him before his

\footnotetext{
71 TsGARKaz F.124 Op.1 D.7 Protokol No.6 08/07/1899 11.69-70

72 This 'reform', carried out under the new Turkestan Statute of 1886, provoked more resistance than perhaps any other Russian interference in the role of local judges: Lykoshin himself wrote that he had only succeeded in forcing qazis of Tashkent to switch to the new steel, state-issued seals by breaking up their old silver ones with a hatchet. N. Lykoshin 'Kazii (Narodnye Sud'i) bytovoi ocherk osedlogo naselenie Turkestana' Russkii Turkestan, Sbornik ['Qazis (Popular Judges). Essay on the daily life of the settled population of 'Turkestan' Russian Turkestan, an Anthology.] Vol.I (Tashkent, 1899) p.34, reprinted in his memoirs Pol zhizni v Turkestane. Ocherki byta tuzemnogo naseleniya [Half a Life in Turkestan. Essays on the daily life of the native population] (Petrograd, 1916) pp.70-1; see Adeeb Khalid The Politics of Muslim Cultural Reform: Jadidism in Central Asia (Berkeley CA, 1998) pp.69-70. However, even before 1886 qazis had used seals issued by the Russian authorities, which in theory were renewed each time they were elected, whilst many also continued to use their old seals alongside them. Paolo Sartori 'Judicial elections as a colonial reform: the Qadis and Biys in Tashkent 1868-1883' Cabiers du Monde Russe 49/1 (2008) pp.79-100 73 TsGARKaz F.124 Op.1 D.7 Protokol Osmotra 08/07/1899 11.68ob - 9; Protokol No.6 08/07/1899 11.70-1 ${ }^{74}$ Here at least Batyrbekov was telling the truth: in 1882 he had been recommended for a gold medal 'for outstanding service' by the acting Governor-General, G. A. Kolpakovskii and had received it with a statement from the chapter that the Tsar had been graciously pleased to bestow it himself $(12 / 07 / 1882)$. His formulyarnyi spisok in this file unsurprisingly does not record any crimes or wrongdoing: Rossiiskii Gosudarstvennyi Voenno-Istoricheskii Arkhiv (RGVIA) F.400 Op.1 D.779 'O pozhalovanii volostnago upravitelya Chimkentskago uezda Karabulakskoi volosti Isa Batyrbekova zolotoyu medal'yu za userdnuyu sluzhbu' $11.2-o b, 9-o b$
} 
'Sufism, Panislamism and Information Panic: Nil Sergeevich Lykoshin and the aftermath of the Andijan Uprising' Past \& Present No.214 (2012) pp.255 - 304

neighbours and in the eyes of the Russian administration. Predictably enough, he claimed that he did not know Mambet Kalkabekov, and that his name had been connected with the case by his political enemies owing to what he called 'party and lineage hostility' of a kind which was common amongst the Kazakhs. ${ }^{75}$ Lykoshin and the Prosecutor did not get the chance to interrogate Batyrbekov until the $4^{\text {th }}$ September, when he repeated his denials, and said that Hal Khoja Afakhojinov had previously been his clerk, but had gone over to 'the party hostile to me, and I sacked him.' He claimed that Muhammad Yusuf was also an enemy, having forged his own seal a few years previously in the course of another set of 'party' hostilities, and that he had not visited him for years. On being challenged with Muhammad Yusuf and Hal Khoja's testimony he changed his story, and admitted that he had in fact entered the former's house in company with the latter some weeks ago on his earnest invitation to drink tea, but had left before any business was discussed, leaving Hal Khoja behind. The interrogation ended with an intriguing, but inconclusive coda: when asked if he had been accompanied by a djigit (bodyguard or runner) Batyrbekov replied that, indeed there had been a djigit with him.

'To the question "was it Mambet?", the witness laughed, and then said Not Mambet', and did not explain the reasons why his recalling of Mambet provoked him to laughter. ${ }^{76}$

There was no more information to be had, either from him or from other Kazakhs of the Buraldaev canton whom Lykoshin interrogated, but who denied everything, whilst a further search of Batyrbekov's property also failed to yield any evidence.

Finally on the $11^{\text {th }}$ September 1899 Lykoshin gathered a group of experts to pass judgement upon the authenticity or otherwise of the 'Afghan' letter, namely Mullah Bahadur Padcha Babakhanov, the qazi of Chimkent, Sultan Ahmad Khoja Sultan Sayyid Khojinov, a mudaris (teacher in a madrasah), ${ }^{77}$ 'Abdullah Khoja Ishan-Khojinov and Mullah Hidayatullah Khoja Babakhoja Ishan, both muftis (legal clerks), and 'Umar Khan 'Abd ul-Ghafarov, the teacher at the local Russian-native school. They unanimously pronounced the letter to be a forgery, pointing out that 1) it was written on Russian-made paper, 2) it was written in crude nastaliq such as no official scribe would use, 3) it contained numerous grammatical errors, 4) it made use of Turkic expressions that were peculiar to Kazakh, and finally 5) the supposed royal seal on the reverse was not of a

\footnotetext{
${ }^{75}$ Ibid petition from Isa Batyrbekov to Lykoshin 04/08/1899 11.91-4ob.

76 Ibid Protokol No.9 04/09/1899 1.98

${ }^{77}$ It is possible that this is the same 'Sultan Ahmad Khan Chimkandlik' who in 1911 published a set of verses criticising the Dukchi Ishan in issue No.82 of the official turkic-language newspaper, Turkistan Wilayatining Gazeti, reproduced at http://zerrspiegel.orientphil.uni-halle.de/t470.html; this is one of the texts discussed in Erkinov The Andijan Uprising of 1898 p.18
} 
'Sufism, Panislamism and Information Panic: Nil Sergeevich Lykoshin and the aftermath of the Andijan Uprising' Past \& Present No.214 (2012) pp.255 - 304

suitable quality, and contained numerous spelling mistakes, including a misspelling of the name of God in 'Habibullah' and a stray alif in 'Rahman'. They concluded that 'the letter was written and the seal cut by the Kirgiz themselves for their own purposes' without going so far as to suggest what these might have been. ${ }^{78}$

Meanwhile, Kalkabekov himself had disappeared from view. In mid-July, not long after the interrogation of the Russian inhabitants of Vysokoe, the assistant to the AulieAta District Commandant wrote to Lykoshin to say that he had vanished from his aul in Kuyuk canton, and that extensive enquiries had failed to reveal his whereabouts. ${ }^{79}$ Eventually on the $12^{\text {th }}$ August 1899 the Commandant of Kopal district, far away in Northern Semirechie (where Kalkabekov had once remarked that he had relatives) wrote to say that he had found him and locked him up in Kopal gaol. ${ }^{80}$ Lykoshin first wrote to ask if he was carrying a seal of any description (which, unsurprisingly, he wasn't) and then on the $22^{\text {nd }}$ August asked for a series of questions about the provenance of the 'Afghan' letter to be put to him. ${ }^{81}$ Unfortunately the Tashkent Prosecutor, Michurin, who clearly had more faith in Kalkabekov's bona fides than Lykoshin did, had already wired to Kopal the day before asking for him to be released. ${ }^{82}$ Lykoshin appears to have bowed to the inevitable, but asked the Kopal District Commandant to give Kalkabekov means to get himself back to Aulie-Ata, so that he could interrogate him personally. After that Kalkabekov turned up briefly in Vernyi, where he was arrested and released almost immediately: he then seems to have disappeared for good. ${ }^{83}$ As Lykoshin rather bitterly remarked in his summing-up of the case

' 1 : Based on the account of the [Russian] peasants of the settlement of Vysokoe, it follows that we should recognise that the outcome of this enquiry into this letter in a native dialect is that it was given to the peasants by the Kirgiz of No.11 aul of the Kuyuk volost' Mambet Kalkabekov, whose whereabouts, notwithstanding exhaustive enquiries, remain unknown, and who according to some accounts can be considered psychiatrically ill. 2: That in producing this letter bearing the seal of Habibullah Abdurrahman Mambet Kalkabekov probably intended that it should serve as a means of spreading slanders about the political undesirability of Kirgiz to whom he and his acquaintance Isa Batyrbekov bore enmity. ${ }^{84}$

It certainly seems more than probable that Kalkabekov had dreamt up the whole tale of a plot by the Dukchi Ishan to distribute weapons amongst the Kazakhs of the distant Chimkent and Aulie-Ata districts as a means of taking revenge on his father-in-law

\footnotetext{
78 TsGARKaz F.124 Op.1 D.7 Protokol 11/09/1899 1l.106-ob

${ }^{79}$ Ibid Aulie-Ata D. C. to Lykoshin, 12/07/1899 11.81-ob

${ }^{80}$ Ibid Kopal D. C. to Lykoshin, 12/08/1899 1.86

${ }^{81}$ Ibid Lykoshin to the Kopal D.C. 22/08/1899 11.89-ob

${ }^{82}$ Ibid Telegram from Michurin to Lykoshin informing him of this 21/08/1899, recd. 22/08/1899 1.90

${ }^{83}$ Ibid Acting Police-Chief, Vernyi, to the Aulie-Ata D. C. 01/09/1899 1.113

${ }^{84}$ Ibdi Lykoshin Postanovlenie No.10 21/12/1899 11.78-ob
} 
'Sufism, Panislamism and Information Panic: Nil Sergeevich Lykoshin and the aftermath of the Andijan Uprising' Past \& Present No.214 (2012) pp.255 - 304

and estranged wife, and other people against whom he bore a grudge; at any rate he had taken advantage of an already-existing rumour to discredit them. No doubt many Kazakhs in the region had hunting rifles which they concealed from the Russian authorities, and it is perfectly possible that stories of the Dukchi Ishan and the miracles he had performed circulated widely (indeed, Anke von Kügelgen suggests that this is the reason why the Manaqib-e Dukchi Ishan was composed), but the tales of weapons being smuggled over the passes from Ferghana, which the administrators of Aulie-Ata and the Tashkent prosecutor lapped up with enthusiasm for over ten months, were almost certainly pure invention. ${ }^{85}$ As a literate man Kalkabekov was also very probably responsible for forging the letter from 'Abd ur-Rahman Khan. Whether he was acting in collusion with (or even under the instructions of the former canton administrator Isa Batyrbekov is less clear: after their interrogation by Lykoshin, Batyrbekov and Hal Khoja Afakhojinov each sent in lengthy petitions denouncing the other. Hal Khoja's contained no fewer than fifteen different criminal allegations against Batyrbekov, only one of which had any relevance to the case, where he claimed that Isa had known an Afghan who had an impression of the seal of the son of 'Abd al-Rahman Khan, and that he had asked the seal cutter in Chimkent to make him a copy. ${ }^{86}$ Perhaps wisely, Lykoshin did not bother following this up. Whilst he clearly continued to regard Batyrbekov with great suspicion, he did not have enough evidence to prosecute him. Thus the elaborate conspiracy the Russians spent over a year and 120 pages of witness statements investigating almost certainly never existed outside the mind of a Kazakh whom Lykoshin had described as 'not entirely sane' when he first met him.

\section{III: Orientalist vs. Kazakh}

Unfortunately, this type of source can tell us little about the main protagonist, the fascinating and elusive Mambet Kalkabekov. The Aulie-Ata District Commandant provided the following description of him when writing to his counterpart in Kopal asking him to carry out a search: ' ... above middle height, skinny, with a small black beard and moustaches, big black eyes, speaks a little Russian, literate 'po-Kirgiaskii [i.e. in Turkic]. ${ }^{87}$ In the letter he wrote for Lykoshin he styled himself 'Mullah', probably indicating that he had received a religious education. ${ }^{88} \mathrm{We}$ know that his mother was 50 , and had been young enough to marry again when his father died or they divorced, and

\footnotetext{
${ }^{85}$ von Kügelgen 'Predisloviya' [Introduction] in Babadzhanov Manaqib pp.29-35

86 TsGARKaz F.124 Op.1 D.7 petition from Hal Khoja Afakhojinov to Lykoshin 20/09/1899 1.126

${ }^{87}$ Ibid Aulie-Ata D. C. to the Kopal D. C. 07/08/1899 11.95-ob

${ }^{88}$ Ibid Mambet Kalkabekov to the Military Governor of Syr-Darya Province 05/05/1899 1.21
} 
'Sufism, Panislamism and Information Panic: Nil Sergeevich Lykoshin and the aftermath of the Andijan Uprising' Past \& Present No.214 (2012) pp.255 - 304

that the mention of his name provoked Isa Batyrbekov to laughter. Beyond this, it is hard to say anything very definite about the man whom the Russians (and his enemies) described as 'insane', but who proved so adept at pressing the right buttons to gain an official response. Instead, we shall have to turn to his principal opponent. Lykoshin's engagement on this case for the latter six months of 1899 did not prevent him from publishing an article on the history of Otrar in December of that year, or one of the very first translations of the Hikmet verses attributed to Khwaja Ahmad Yasavi, ${ }^{89}$ but perhaps unsurprisingly he never seems to have referred to the case of Mambet Kalkabekov in any of his published writings. ${ }^{90}$ Along with what seems to have been a natural shrewdness and energy, it is clear that Lykoshin's skills as an Orientalist - and above all the fact that he could speak and understand Turkic - helped bring this case to a close: it was he who first cast doubt on Kalkabekov's testimony after several Russian administrators who did not speak the vernacular had gone out of their way to insist on its trustworthiness. It was he whose interrogations and investigations had revealed Kalkabekov's hand behind the spurious 'Afghan' letter and the possible involvement of a powerful local politician, whilst he also had had the necessary connections with the 'ulama of Chimkent to assemble a group of Muslim scholars who could dismiss it as a forgery. Reading between the lines, one suspects that had it not been for the insistence of the Tashkent prosecutor, Michurin, who had clearly been taken in by Kalkabekov from the first, Lykoshin would never even have bothered with an investigation. He had already worked out the true nature of the 'Afghan' letter after the first interrogation of the settlers of Vysokoe, whilst he never seems to have given any credence to Kalkabekov's initial stories about the Dukchi Ishan. The value of a skilled Orientalist to the colonial administration - in this instance dispelling prejudices about Muslim 'fanaticism' rather than reinforcing them - could hardly be more clearly demonstrated. Nevertheless, the investigation had already been running for ten months by the time Lykoshin got involved: what is really noteworthy here is the amount of time and effort which were spent following up allegations which should have been dismissed out of hand to begin with, as soon as the police chief had spoken with Kalkabekov's father-in-law and estranged wife.

\footnotetext{
${ }^{89}$ N. Lykoshin 'Dogadka o proshlom Otrara' ['Hypothesis on the past of Otrar'] TV $2^{\text {nd }}$ Dec. 1899 No.94; N. Lykoshin 'Premudrost' Hazrat Sultana Afirin-Khodzha Akhmada Yasavi' ['The wisdom of Hazrat Sultan Afirin-Khoja Ahmad Yasavi'] Sbornik materialov dlya statistiki Syr-Dar'inskoi oblasti [Anthology of material for the statistics of Syr-Darya province] Vyp.IX Otd.2 (Tashkent, 1901) pp.76-105

${ }^{90}$ Unless, that is, there is an oblique reference to it in his review of two brochures on Kazakh customs by I. V. Anichkov, published a few days before he began his interrogations in Vysokoe, in which he referred to the inability of Kazakhs to tell the truth in Russian courts owing to the degree of party hostility which always existed between them: N. Lykoshin 'Bibliograficheskaya zametka' ['Bibliographical Remarks'] TV $1^{\text {st }}$ July 1899 No.50
} 
'Sufism, Panislamism and Information Panic: Nil Sergeevich Lykoshin and the aftermath of the Andijan Uprising' Past \& Present No.214 (2012) pp.255 - 304

This is all the more striking, given that just three years earlier in 1895-6 there had been a similar case in the Aulie-Ata district, when a village headman named Kermal Shiralin, together with his brother and a local mullah, accused an ishan called Izrail-TuraBek Ishanov of claiming to have royal blood, and of plotting an uprising against the Russians amongst the 'Kara-Kirgiz' (i.e. Kyrgyz) of the Karabiral'sk and Urmaral'sk cantons. In this instance the case was resolved rather more quickly, and within less than a year the three accusers had been sentenced to a year and a half in gaol. ${ }^{91}$ However, even so the investigation of the case lasted almost three months, and Lt-Col Lazhechnikov, the then assistant to the Aulie-Ata District Commandant, had taken 125 lengthy witness statements before he realised that he was dealing with a clumsy attempt at slander. ${ }^{92}$ Although none of the same men were involved, it seems curious that this precedent should not have occurred to the officers of the Aulie-Ata district when they began investigating Kalkabekov's allegations, but there is not even a mention of it in the file. This is perhaps partly attributable to an exaggeration of the danger of a revolt by the officers involved in the hope that they would gain credit for having nipped a genuine conspiracy in the bud, although the irritable tone of the Aulie-Ata District Commandant's letters to the Tashkent prosecutor, and Lykoshin's evident belief that the latter had despatched him on a wild goose chase suggest otherwise. There may also have been a sense that they had been too blasé about that case, which did involve a genuine ishan from Andijan, temporarily resident in the Aulie-Ata district, ${ }^{93}$ a circumstance which would have been viewed with much greater suspicion after 1898: the Andijan uprising was to cast a very long shadow over Turkestan officialdom's view of Islam.

\footnotetext{
${ }^{91}$ TsGARKaz Fond 149 Mirovoi Sud'ya 1-go uchastka Aulie-Atinskogo uezda [Magistrate's Court of the $1^{\text {st }}$ Division of the Aulie-Ata district] Op.1 D.16 'Po obvineniyu kirgizy Urmaral'skoi volosti Aulie-Atinskogo uezda Arzykula Shiralina, Kermala Shiralina i Mully-Galiya Baikulova v lozhnom donose o vosstanii protiv russkikh vlastei' [On the prosecution of the Kirgiz of the Urmaral'sk canton of Aulie-Ata district Arzykul Shiralin, Kermal Shiralin and Mullah-Galiya Baikulov for a false deposition about an uprising against Russian power] Rezolyutsiya [Resolution] 24/01/1896 11.25-9

${ }^{92}$ TsGARKaz Fond 433 Mirovoi Sud'ya 2-go uchastka Aulie-Atinskogo uezda [Magistrate's Court of the $2^{\text {nd }}$ Division of Aulie-Ata Province] Op.1 D.1 'Po obvineniyu Musul'manskogo knyazya Izrail Ishan Bekishanova, ego syna Kamaldina Izrailogo - i Kazakha Aulie-Atinskogo uezda Bai-Seiit Kulzhabekova, Shirbaya Mambetova i Aidasha Naimanbaeva za podgotovka vosstanii protiv Russkikh' ['On the prosecution of the Muslim Prince Izrail Ishan Bekishanov, his son Kamaldin Izrailov and the Kazakhs of the Aulie-Ata District Bai-Seiit Kulzhabekov, Shirbai Mambetov and Aidash Naimanbai for preparing an uprising against the Russians'] Vol.1 11.17-159, Vol.2 11.8-54.

${ }^{93}$ TsGARKaz F.149 op.1 D.16 Protokol 05/03/1895 1l.57ob-8. This case has a number of points of interest, and would in itself deserve further study. Here, as with Kalkabekov in 1899, the accusers attempted to route their denunciation via the local settler population, in this instance Mennonites of the village of Orlovka. Furthermore 'Izrail-Bek-Tura', a Ferghana ishan with a Kyrgyz wife, who visited the Aulie-Ata district every two years or so and clearly had an extensive following there, is an intriguing figure in his own right, even if he wasn't intriguing against the Russians.
} 
'Sufism, Panislamism and Information Panic: Nil Sergeevich Lykoshin and the aftermath of the Andijan Uprising' Past \& Present No.214 (2012) pp.255 - 304

\section{IV: The Legacy of Andijan}

The behaviour of the officers in this case, and their willingness to believe what on the face of it seems an entirely fantastic story about an intrigue managed by the Dukchi Ishan from beyond the grave in collusion with the Amir of Afghanistan starts to become more comprehensible if we look at the report of the official enquiry into the Andijan Uprising, as well as Governor-General Dukhovskoi’s personal response to it. Lt-Gen F. M. Korol'kov of the General Staff, who was charged with mounting the investigation, devoted a great deal of attention to the supposed links between the ishan and the international forces of pan-Islam. Whilst the Russians themselves had demonstrated that the farman which the ishan believed he had received from the Ottoman Sultan was a forgery, ${ }^{94}$ Korol'kov nevertheless wrote:

'Already these facts alone demonstrate that there were Turkish and Afghan emissaries in Turkestan, and further enquiries in this regard would doubtless yield firm information, confirming the hostile activities towards us of agents from Turkey and Afghanistan. It is their activities that we have to thank for the noticeable fanatical disturbances amongst the native population in recent times, visible all over Central Asia in various unpleasant actions towards Russian people; thus, not long ago in Aulie-Ata the Kirgiz insulted and treated with violence two NCOs, without the slightest provocation on the part of the latter... 95

The incident in Aulie-Ata referred to here perhaps contributed to the credulity of its officers in 1898. This insistence that any signs of unrest must be the work of 'foreign agents', and heroic refusal to even consider the possibility that the inhabitants of Turkestan might have other reasons to resent colonial rule were, of course, not peculiar to the Russians; such sentiments can often be found in official circles in India (where the Russians were sometimes blamed for supporting Nationalist agitation). However the attribution of a peculiarly malignant 'fanaticism' to Islam, the thread which runs throughout the whole of the enquiry, was arguably more exaggerated in the Russian Empire than anywhere else. ${ }^{96}$ This was partly owing to earlier fears generated by the long war against the Chechens and Daghestanis in the North Caucasus. This was an experience Governor-General Dukhovskoi (who had served in the Caucasus war in his youth) referred to in his equally paranoiac (and in some places downright bizarre) report a year later, and the conclusion he drew from it was that 'Musulman-Sufists [sic] are in many

\footnotetext{
${ }^{94}$ Komatsu 'The Andijan Uprising Reconsidered' p.42

${ }^{95}$ F. M. Korol'kov 'Otchet po razsledovanie obstoyatel'stv tuzemtsev Ferganskoi oblasti v Mae 1898g' ['Report of the inquiry into the circumstances of the natives of Ferghana province'] (Tashkent, 03/08/1898) p.18 At least a hundred copies of this were printed at Dukhovskoi's request. The one I consulted is in RGVIA F.483 Op.1 D.137; the bulk of this report was reprinted in Shteinberg (ed.) 'Andizhanskoe Vosstanie 1898g' pp.144-160, where this quotation falls on p.154

${ }^{96}$ At least in the Caucasus and Turkestan - the situation in the Volga region was different, as there Muslims were full citizens of the empire and had access to civic institutions such as the zemstvo. See Robert Crews For Prophet and Tsar. Islam and Empire in Russia and Central Asia (Cambridge, MA, 2006) pp.31-142.
} 
'Sufism, Panislamism and Information Panic: Nil Sergeevich Lykoshin and the aftermath of the Andijan Uprising' Past \& Present No.214 (2012) pp.255 - 304

respects much more dangerous to us than Orthodox Muslims.${ }^{97}$ Pan-Islamism also worried him, although he concentrated mainly on undesirable influences from the Ottoman Empire which were reaching Central Asian Muslims via the Kazan Tatars. These official sentiments, whilst they were not always taken very seriously at the centre (Witte largely dismissed Dukhovskoi's concerns and suggestions), ${ }^{98}$ became widely disseminated in Turkestan and across the Empire, through lurid publications such as V. P. Sal'kov's Andizhanskoe Vosstanie, which amongst other things accused the ishan of raping a minor, through numerous articles in the official Turkestanskiya Vedomosti, ${ }^{99}$ and through the equally islamophobic Sbornik materialov po Musul'manstvu, compiled by order of the Samarkand Military Governor, Major-General Fedorov, a copy of which was placed in every district chancellery. ${ }^{100}$ The Russian colonial administration in Turkestan remained deeply pessimistic about the obstacles which Islam placed to their long-term goal of assimilating the region to the rest of the Empire, and heavily preoccupied by the Islamic threat to their rule right up until the 1916 Revolt.

Some Russian officials were aware of how counter-productive all this could be: in an article published in the Istoricheskii Vestnik on the tenth anniversary of the uprising in 1908, an officer writing under the pseudonym 'T-ov' poured scorn on the official explanation that the Andijan uprising was a product of implacable local fanaticism fanned by shadowy 'emissaries' from the Ottoman sultan and the Afghan Amir. Writing that true 'fanatics' were only rarely to be encountered amongst the population of Turkestan, and that the evidence put forward for foreign, pan-Islamic involvement was absurdly flimsy, he instead argued that the ishan and his followers were concerned at the moral decay they

\footnotetext{
${ }^{97}$ Dukhovskoi 'Vsepoddanneishii doklad Turkestanskogo general-gubernatora' pp.149-151; Babajanov has suggested that Dukhovskoi's report was drafted by V. P. Nalivkin and N. P. Ostroumov, two other Orientalists who worked as administrators in Turkestan 'Andizhanskoe vosstanie 1898 goda i “musul'manskii vopros" v Turkestane' pp.166-177; On the exaggerated role attributed to Naqshbandi Sufism in stimulating resistance to Russian rule, see Alexander Knysh 'Sufism as an Explanatory Paradigm' Die Welt des Islams 42/2 (2002) pp.139-173.

98 'Zapiska S. Yu. Witte po "Musul'manskomu Voprosu” 1900g' ['S. Yu. Witte's notes on the "Muslim Question" '] in Arapov (ed.) Imperatorskaya Rossiya pp.244-57

${ }^{99}$ Sal'kov "Andizhanskoe vosstanie" pp.32, 54; The title-page of the Bodleian's copy (which bears an autograph showing it was presented by the author to General Sakharov, the Chief of the the General Staff), has a label indicating that the Ministry of National Enlightenment's scholarly committee had ordered the book to be placed in 'all student libraries of lower national schools and free reading-rooms'. See also N. Sitnyakovskii 'Mintyubinskii ishan Mukhamed-Ali' ['The Ming-Tepe ishan Muhammad Ali'] TV Jan-Feb 1899 Nos. 2, 8, 16, which is the source for many of the nastier stories about the ishan repeated by Sal'kov.

${ }^{100}$ See in particular E.T. Smirnov 'Dervishizm v Turkestane' \& 'Dzhikhad i Gazavat' ['Dervishism in Turkestan' \& 'Jihad and Ghazavat'] V. I. Yarovoi-Rabskii (ed.) Sbornik materialov po Musul'manstvu [Anthology of Materials on Islam] Vol.1 (St Pb., 1899) pp.49-71, 101-128; The tone and content of this publication were heavily criticised by the Orientalist V. V. Barthold: Komatsu 'The Andijan Uprising Reconsidered' pp.49-50;
} 
'Sufism, Panislamism and Information Panic: Nil Sergeevich Lykoshin and the aftermath of the Andijan Uprising' Past \& Present No.214 (2012) pp.255 - 304

saw all around them in Turkestan, exemplified by the spread of drunkenness and prostitution under Russian rule. ${ }^{101}$

'The official enquiry, which was carried out with the aim of revealing the true reasons for the uprising of 1898, made it clear that the reason consisted almost exclusively of the fanaticism of Muslims, who are fundamentally intolerant towards their masters, the kafirs; the smouldering fanaticism in the population only awaited a suitable moment to burst into flame. In official matters all the Andijan carnage was attributed exclusively to the advent of the ishan, his all-round popularity, they hinted at the involvement of the Turkish Sultan and the Emir of Afghanistan, but this went no further. The powers that be, having clarified the reasons behind this deplorable episode, whether through oversight or deliberately, entirely excluded the possibility that dissatisfaction only manifests itself where there is fertile ground.'102

He also wrote that both the problems which led to the revolt and the failure to foresee it were owing to the inadequate training of Russian administrators, District Commandants and police chiefs, who since the introduction of the new Turkestan statute of 1886 had been encouraged to view Islam as a dangerous fanatical enemy, and not to uphold the moral tenets of the shari' $a$. 'T-ov' harked back to a supposed golden age under Turkestan's first Governor-General K. P. von Kaufman, when Islam had been tolerated to a greater extent (in fact Kaufman, as revealed in his actions, writings and recorded pronouncements to others, was a great believer in Muslim 'fanaticism', although he believed that his policy of ignorirovanie had reconciled Turkestan to Russian rule and would eventually be sufficient to woo Muslims from their faith). ${ }^{103}$ T-ov's identity remains unclear, but very similar criticisms of Russian policy are found in the 1914 memoirs of the Samarkand administrator A. I. Termen. ${ }^{104}$ The orientalist-administrator V. P. Nalivkin is another possibility: Sergei Abashin has recently demonstrated that Nalivkin underwent some sort of political and moral epiphany in the years 1905-6, which saw him transformed from a loyal and brilliant servant of the colonial regime to a radical socialist and one of its severest critics. ${ }^{105}$ Whoever the author was, his interpretation of the causes of the Andijan

\footnotetext{
101 'T-ov' 'Andizhanskoe vosstanie i ego prichiny' ['The Andijan Uprising and the reasons for it'] Istoricheskii Vestnik No.5 (1908) pp.664-6

102 'T-ov' 'Andizhanskoe vosstanie' p.664

103 Gen.-Ad't. K. P. fon-Kaufman Proekt vsepoddanneishego otcheta Gen.-Ad'yutanta fon-Kaufmana po grazhdanskomu upravleniyu [Draft of the general report of Adjutant-General von Kaufman on civilian administration] (St Pb., 1885) p.10; N. P. Ostroumov Konstantin Petrovich fon-Kaufman, ustroitel' Turkestanskogo Kraya. Lichnyya vospominaniya 1877-1881gg. [Konstantin Petrovich von Kaufman. The founder of the Turkestan region. Personal reminiscences 1877-1881] (Tashkent, 1899) p.11; Khalid Muslim Cultural Reform pp.51-3

104 A. I. Termen Vospominaniya administratora. Opyt' issledovaniya printsipov upravleniya inorodtsev [Reminiscences of an administrator. Experience derived from researching the principles for ruling aliens] (Petrograd, 1914) pp.3-4, 20; See Morrison Russian Rule in Samarkand pp.151-7 for a discussion of Termen and his text. 105 S. N. Abashin 'V. P. Nalivkin. "budet to, chto neizbezhno dolzhno byt; i to, chto neizbezhno dolzhno byt, uzhe ne mozhet ne byt.” Krizis Orientalizma v Rossiiskoi Imperii?’ ['V. P. Nalivkin. “That which inevitably must be will be; and that which inevitably must be already cannot fail to be." A crisis of Orientalism in the Russian Empire?'] in Yu. P. Rodionov \& A. V. Yakub (ed.) Aziatskaya Rossiya. Liudi i struktury Imperii [Asiatic Russia. People and Structures of the Empire] (Omsk, 2005) pp.43-96; certainly the Nalivkin who wrote an official report for Governor-General Dukhovskoi in 1899 entitled 'Zapiska o
} 
'Sufism, Panislamism and Information Panic: Nil Sergeevich Lykoshin and the aftermath of the Andijan Uprising' Past \& Present No.214 (2012) pp.255 - 304

uprising did not long remain unchallenged. A few weeks later Lykoshin, now

Commandant of the Khujand district in Samarkand province, published a lengthy rebuttal of 'T-ov's allegations in the official Turkestanskiya Vedomosti. Lykoshin began by acknowledging that the ishan had not been the only one to complain about the 'moral decay' brought about by Russian rule.

'This accusation is something every Russian who has lived for a long time in the region has heard more than once from natives of his acquaintance: "you have given us drunkenness, legalised the existence of brothels, weakened the sense of responsibility for crime amongst the people" say our accusers. Thus one cannot but agree with the author of this analytical article, citing the testimony of ishan Madali, that the weakening of morals in the region, or, more accurately, of order and decency, in the hands of ishan Madali turned out to be a powerful means and a significant cause for struggle against Russian power. ${ }^{106}$

However, Lykoshin considered this to be only one contributing factor to the outbreak, and by no means the most important one. Instead, he argued, the crucial reasons (in order of importance) were:

1: The savagery of the Ferghana Kyrgyz.

2: Muslim fanaticism.

3: The baleful influence of native officials opposed to Russian interests, some of whom had placed their seals on the Dukchi Ishan's proclamation.

4: The 'Stone Wall' of the native administration, which cut off Turkestan's natives from the true benefits of Russian civilisation.

Lykoshin's sentiments on this last point would be echoed at greater length five years later by Nalivkin, who also bemoaned the existence of what he called the 'Living Wall' separating rulers and ruled. ${ }^{107}$ Russian contempt of and suspicion of the class of native officials they had themselves created is a common trope in both published and archival sources of this period, and had probably contributed to the authorities deciding to ignore the accusation of cattle-raiding made by the local judge and other officials against their informant, Mambet Kalkabekov. Leaving this point aside for the moment though, in light of what we now know of Lykoshin's role in working with the 'ulama to calm fears of 'fanaticism' and pan-Islamic conspiracy in the immediate aftermath of the

vozmozhnykh sootnosheniyakh mezhdu poslednim sobytiem v Kitae i usileniem panislamistskogo dvizheniya' ['Notes on the possible connections between the recent events in China and the strengthening of the panislamist movement'] (reprinted in Arapov Imperatorskaya Rossiya pp.181-190) and who edited the Sbornik materialov po Musul'manstvu which appeared in 1900 must have been a very different character from the one who wrote the polemical Tuzemtsy, ran'she i teper' [Natives, before and now] (Tashkent, 1913) and became the head of the Provisional Government's Turkestan Committee after the February Revolution. However, even in the latter work (p.75) he was still referring to the influence of pan-Islamism on the population of Turkestan.

${ }^{106}$ N. S. Lykoshin 'K desyatiletiyu Andizhanskoi rezni (1898-1908g)' ['On the tenth anniversary of the Andijan carnage'] TV 30th May 1908 No.115

107 Nalivkin Tuzemtsy p.71 
'Sufism, Panislamism and Information Panic: Nil Sergeevich Lykoshin and the aftermath of the Andijan Uprising' Past \& Present No.214 (2012) pp.255 - 304

Andijan uprising, his analysis here is puzzling. Surely he had learnt from direct experience that the Russian belief in the undifferentiated 'fanaticism' of their Muslim subjects was flawed, and actually damaging to good administration? Yet here he seems to be reflecting precisely the same prejudices. There are, I think, at least two solutions to this puzzle, elements of which are to be found elsewhere in the article and in some of Lykoshin's other writings, which between them shed some interesting light on the late-Imperial 'official mind' of Russian Turkestan.

\section{V: Lykoshin, Islam and Grazhdanstvennost'}

In some of his earliest pieces, written under a pseudonym for the Samarkand newspaper Okraina, Lykoshin had launched an attack on the Crimean Tatar reformer Ismail Bey Gaspirali, accusing him of fostering disloyalty and separatism amongst Russia's Muslims: ${ }^{108}$ Lykoshin saw Islam, even in its modernising form, as an insuperable obstacle to the acceptance by Central Asians of Russian grazhdanstvennost' or 'civic values', and whilst his understanding of Islam increased over time, his opinion on this point did not change. However, Lykoshin's idea of Islamic ‘fanaticism' did not necessarily imply violence or unthinking prejudice:

'One cannot deny Muslim fanaticism. The feeling of dissatisfaction with a government of unbelievers, or rather, dissatisfaction with the situation of subjection to such a Government, is something that lives and will continue to live in the popular consciousness, because Islam, which treats at length of the relations between conquering Muslims and conquered unbelievers (dhimmi), does not have a word to say about how conquered Muslims should relate to conquering unbelievers. It is not envisaged at all, and hence these relations are not regulated. Under these circumstances it would be naïve to expect love and devotion.' ${ }^{109}$

Lykoshin's presentation of this question was thus very textual: despite his own direct experience of Islam's many shifts and accommodations to colonial rule in Turkestan, he preferred to invoke a lack of necessary scriptural sanction and regulation which, in his view, made a true reconciliation impossible. Lykoshin's skills as an orientalist certainly made him a much more effective administrator, and allowed him to see through things which confused and misled other Russian officials in the region. However, perhaps they also blinded him to the fact that, apart from Andijan, there had been remarkably little Islamically-motivated resistance to Russian rule in Turkestan since the 1870s: his reading of Islamic scripture appears to have overridden the evidence of his own experience.

\footnotetext{
108 "Mirshab" 'Voina s nevernymi i voinstvuyushchii Tatarskii listok' ['War with the unbelievers and a militant Tatar leaflet'] Okraina 1890 No.232, 1891 Nos. 9, 42; in earlier work I misidentified the author of these articles as the islamophobic writer Miroslav Miropiev, and its tone is much harsher than Lykoshin's later writings, but Baskhanov suggests he published other pieces in Okraina under the pseudonym 'Mirshab' ('nightwatchman'). Morrison Russian Rule in Samarkand 1868-1910 p.76; Baskhanov Voennye vostokovedy p.146 ${ }^{109}$ Lykoshin 'K desyatiletiyu Andizhanskoi rezni' TV 31 st May 1908 No.116
} 
'Sufism, Panislamism and Information Panic: Nil Sergeevich Lykoshin and the aftermath of the Andijan Uprising' Past \& Present No.214 (2012) pp.255 - 304

The other possible reason for Lykoshin's stance was more political. His intervention in the reflections on the $10^{\text {th }}$ anniversary of Andijan was part of a much wider debate which had been taking place since at least the mid-1880s over the need for administrative reform in Turkestan, and whether the region was ready for greater sblizhenie in the form of civilian rule. ${ }^{110}$ At the time when this exchange took place Count

Konstantin Konstantinovich Pahlen's reforming commission was touring Turkestan, and this debate had been re-opened with particular urgency. ${ }^{111}$ Lykoshin referred at the beginning of the article to the possible introduction of civilian rule, and many of his arguments about the persistence of Islamic 'fanaticism' were clearly designed to combat this idea. ${ }^{112}$ Instead he urged an end to elections in the native administration (a view that was widely shared amongst Russian administrators), ${ }^{113}$ and an improvement in the calibre of those officers appointed to administrative posts:

'If russification [obrusenie], even if it is somewhat forcible, is to be an aim of our policy here, then all must act with solidarity, all applying their force in one and the same direction $[\ldots]$ The administration must be Russian, Russian without fail, in all positions, beginning from the police pristav, but the personnel must be thoroughly improved and well-furnished. The thorough improvement of the make-up of the administration under current conditions will only be possible with a significant increase in pay, and with this a raising of the requirements expected of those who wish to occupy administrative posts. ${ }^{114}$

Lykoshin then harked back to an earlier era, when, so he claimed, it had been easier to attract good officers into the administration because there was a greater pay differential between that and straight military service; he also complained that nowadays District Commandants were largely desk-bound, filling in forms in their chancelleries rather than getting out of the office to administer their districts - a complaint which carries a remarkable ring of familiarity to anyone who has studied the Indian Civil Service and its discontents in the same period. ${ }^{115}$ Above all though, Lykoshin was arguing for the continuance of firm military government, without institutions such as the zemstvo or civilian courts which would have diluted the paternal authority of officers such as him:

\footnotetext{
110 Sblizhenie, 'drawing closer' or rapprochement, the process that was supposed to incorporate non-Russian borderlands and peoples into the main body of the empire. On this debate see Daniel Brower Turkestan and the Fate of the Russian Empire (London, 2003)

111 See Richard Pierce (ed.) Mission to Turkestan. Being the memoirs of Count K. K. Pablen 1908-1909 trans. N. J. Couriss (Oxford, 1964); Senator Gofmeister Graf K. K. Palen Otchet po revizii Turkestanskago Kraya, proizvedennoi po VYSOCHAISHEMU poveleniyu... [Report on the inspection of the Turkestan region, carried out under the HIGHEST auspices...] (St Pb., 1910-11) 20 Vols + appendices. The Pahlen Commission's report remains an invaluable resource for historians of Turkestan, but its modest proposals for the extension of civilian institutions to the region were stymied by bureaucratic opposition in both Tashkent and St Petersburg.

${ }^{112}$ Lykoshin 'K desyatiletiyu Andizhanskoi rezni' TV 1908 No.115

113 Morrison Russian Rule in Samarkand pp.193-5

${ }^{114}$ Lykoshin 'K desyatiletiyu Andizhanskoi rezni' TV 1908 No.116

115 David Gilmour The Ruling Caste. Imperial Lives in the Victorian Raj (London, 2005) pp.215-7
} 
'Sufism, Panislamism and Information Panic: Nil Sergeevich Lykoshin and the aftermath of the Andijan Uprising' Past \& Present No.214 (2012) pp.255 - 304

Just as fire can only be fought with fire, so the jealousy which has built up over centuries amongst the people can only be neutralised by sincere, hearty relations with the people we have conquered, and against those forces, such candour and goodwill will yield neither to Muslim fanaticism, nor to the sluggishness of the native population.'116

In April 1916, shortly before the rebellion which marked the effective end of the old colonial system in Turkestan, Lykoshin published his 'memoirs' (much of the volume actually consisted of a republication of earlier pieces). ${ }^{117}$ Although he wrote of his belief that the wealthy and educated Muslims of Turkestan already understood the benefits of Russian rule, and continued to express serene confidence that the civilising benefits Russia had brought would eventually undermine Islam, Lykoshin continued to express unease at the continued adherence of the natives to Islam, their separation (as he saw it) of the world into the entirely unconnected spheres of believers and kafirs, and their lack of appreciation for the virtues of Russian civilization, or graz̧bdanstvennost. ${ }^{118}$

\section{VI: Rebellion and Revolution}

Reflecting on his career in the very different political circumstances of 1919, Lykoshin would later write that he had always seen it as his duty to bring Russians and natives closer together - in other words to bring about sblizhenie, or rapprochement. ${ }^{119} \mathrm{He}$ was certainly unusual amongst Tsarist administrators in his knowledge of the local languages and culture of Central Asia, and, as we have seen, he had direct administrative experience of the confusion which could be produced by official ignorance and paranoia. Nevertheless, even he remained convinced that Islam by its very nature represented the most likely inspiration for a rebellion, and the single greatest obstacle to the firm establishment of Russian rule in the region. This appears to have blinded him to more urgent causes of discontent in Turkestan which gathered strength throughout the early 1900s and came to a peak in the 1916 revolt, notably the occupation of arable and grazing land by Russian peasant settlers, increased wartime taxation and, finally, the fateful decision to extend conscription to Turkestan's Muslim population. ${ }^{120}$ Lykoshin was one of

\footnotetext{
${ }^{116}$ Lykoshin 'K desyatiletiyu Andizhanskoi rezni' TV 1908 No.116

117 It received a glowing anticipatory write-up from an American missionary called Eleonora Dickson (or Dixon), who was touring Turkestan at the time and who seems to have been very taken with Lykoshin: Eleonora Dikson 'Pol zhizni v Turkestane' ['Half a life in Turkestan'] Turkestanskii Kur'er (TK) 19 ${ }^{\text {th }}$ March 1916 No.63

118 Lykoshin Pol zhizni v Turkestane pp.5-16

119 Tsentral'nyi Gosudarstvennyi Arkhiv Respubliki Uzbekistan [Central State Archive of the Republic of Uzbekistan (TsGARUz)] Fond R-2499 'Lykoshin, Nil Sergeevich' Op.1 D.4 'Zhizneopisanie' [autobiography] 8/02/1919 1.1; my profound thanks to Shioya Akifumi for letting me use a copy of this short autobiography, now held in Lykoshin's personal Fond in the Uzbek archives, where I am currently unable to work.

${ }^{120}$ Although, as Tomohiko Uyama points out, some Kazakh leaders did describe the 1916 revolt as a 'ghazavat', in other cases mullahs used the shari' $a$ as an argument against the revolt. 'Two attempts at building
} 
'Sufism, Panislamism and Information Panic: Nil Sergeevich Lykoshin and the aftermath of the Andijan Uprising' Past \& Present No.214 (2012) pp.255 - 304

the committee which drew up the conscription protocols in July 1916, and he did not anticipate that there would be significant resistance, let alone that it would turn violent. ${ }^{121}$ Under these circumstances, it is hardly surprising that the rebellion which followed caught the colonial administration entirely unprepared, but the myth of Islamic conspiracy persisted. In his official report to the Tsar on the causes of the uprising, the new Governor-General Alexei Kuropatkin still made reference to the role of the 'ulama in stirring up rebellion, and to German, Turkish and Afghan agents. ${ }^{122}$ Lykoshin himself also believed that Panislamism had been at work, ${ }^{123}$ but for him the uprising represented above all a decisive rejection of Russia's civilising mission. For this he blamed, ultimately, his fellow officers 'We failed during the 50 years of our presence in the region to win the confidence of the natives' for whom the Russians had remained 'infidels'. ${ }^{124}$ The bettereducated, better-paid, more enlightened Turki-speaking Russian administrators whom he hoped might bridge this gap, envisaged in his article on the Andijan uprising eight years before, had never materialised.

Lykoshin might not have been able to anticipate the revolt, but he would use his linguistic skills to defuse tensions amongst the population of the city of Samarkand, which remained peaceful. In his capacity as Military Governor he also successfully suppressed the exceptionally fierce uprising in Djizak district, where forty-nine settlements were wholly or partially burnt to the ground, including the centre of the town of Djizak. ${ }^{125}$ After the revolution Lykoshin would claim that he was not personally responsible for this, and that in fact he had been instrumental in seeing that the inhabitants of Djizak were not expropriated under General Kuropatkin's ruthless policy of expelling Muslims and replacing them with Russian settlers 'wherever Russian blood was shed'. ${ }^{126}$ In January 1917 Lykoshin was dismissed from the post of Military Governor of Samarkand, possibly

\footnotetext{
a Qazaq State: The Revolt of 1916 and the Alash Movement' in Stèphane Dudoignon \& Hisao Komatsu (ed.) Islam in Politics in Russia and Central Asia (London, 2001) pp.85-6

121 Brower Turkestan p.157

122 P. Galuzo (ed.) 'Vosstanie 1916g. v Srednei Azii' ['The 1916 Uprising in Central Asia'] KA Vol.34 (1929) p.75; Happel Nomadische Lebenswelten pp.161-7

${ }^{123}$ Brower Turkestan p.159

124 TsGARUz F.I-1 'Kantselyariya Turkestanskogo General-gubernatora' Op.27 D.296 'Protokol soveshchanii po rasmotreniyu osnovnykh polozhenii ob upravlenii’ [Minutes of the conference for the examination of the fundamental conditions of rule] ?/09/1916 11.115-6ob, 125, cited in Brower Turkestan p.6 125 Richard Pierce Russian Central Asia 1867-1917 (Berkeley CA, 1960) p.273; A. Shestakov (ed.) 'Dzhizakskoe vosstanie v 1916g.' ['The Djizak Uprising in 1916'] KA Vol.5 (60) 1933 p.91

${ }^{126}$ Nil Lykoshin 'Grazhdanin Redaktor!' ['Citizen Editor!'] TK 28 ${ }^{\text {th }}$ August 1917 No.188; Given that Lykoshin was by then trying to defend his reputation in a hostile post-revolutionary atmosphere, it is not clear how much credence can be lent to this claim.
} 
'Sufism, Panislamism and Information Panic: Nil Sergeevich Lykoshin and the aftermath of the Andijan Uprising' Past \& Present No.214 (2012) pp.255 - 304

because he had fallen out with Kuropatkin over this question, ${ }^{127}$ although the proximate cause appears to have been his attempts to fix the price of sugar in the Samarkand bazaars. ${ }^{128}$ Later Lykoshin himself would write that his resignation was owing to ill-health, brought on by forty years of service 'in the dust and beneath the southern sun'. ${ }^{129}$ It was this, together, perhaps, with the fact that he had already left his post before the February Revolution, which meant that he did not immediately share in the opprobrium which then fell on Kuropatkin and many other Tsarist administrators in Turkestan.

Lykoshin's limited notions of 'progressiveness' would soon be overtaken by events. In March 1917 he published an article ostensibly addressed to 'Native Citizens!' (but presumably intended largely for a Russian readership) in the liberal daily Turkestanskii Kur'er, in which he reflected on the implications of the citizenship which the Provisional Government was proposing to grant to the natives of Turkestan. In this he referred once more to the Andijan uprising, accepting that it had demonstrated the dissatisfaction of many 'natives' with the Russian order of things, in particular the decline in public morals and the abuses of the native administration. His assessment of the 1916 revolt was much more severe:

'Our native fellow-citizens were presented with a demand to fulfil the smallest part of their duty to the motherland, in a year of unparalleled military strain. Our natives had never been citizens. They had always been merely members of a single all-Muslim religious society, regardless of the frontiers of whatever state they happened to live in. ${ }^{, 130}$

Lykoshin blamed their failure to fulfil this duty and the violence which had resulted partly on this lack of identification with the state, but also on the poor management of the authorities, who had allowed wild rumours and panic to spread. Once again, he bemoaned a lack of officers sufficiently acquainted with the local languages, and also made some veiled criticisms of Kuropatkin's handling of the revolt. Finally he described a political meeting which had recently taken place in Samarkand, where exmembers of the native administration sacked for corruption under the old regime were

\footnotetext{
${ }^{127}$ Kuropatkin had been briefed against Lykoshin by General Pokotilo, the former Governor of Semirechie, before he returned to Turkestan as Governor-General, referring to him in his diary entry for the $23^{\text {rd }}$ July 1916 as 'blind' (and mis-spelling his name). Galuzo 'Vosstanie 1916g.' p.46

128 B. V. Lunin 'Nil Sergeevich Lykoshin' Istoriografiya obshchestvennykh nauk v Uzbekistane. Bio-Bibliograficheskie ocherki [Historiography of the social sciences in Uzbekistan. Bio-bibliographical sketches] (Tashkent, 1974) p.216; There were rumours that he had been speculating illegally in sugar, but Oksana Pugovkina has suggested to me that he had simply been trying to hold the prices down in Samarkand when wartime food shortages caused rocketing inflation: the accusation was made by a Social Democrat deputy of the Tashkent City Duma, Chernovskii, as part of a speech objecting strongly to Lykoshin's candidacy for mayor: 'Gorodskaya Duma' ['The City Duma'] TV 20th August 1917 No.122

${ }^{129}$ TsGARUz F. R-2499 Op.1 D.4 8/02/1919 1.2

${ }^{130}$ N. S. Lykoshin 'Grazhdane Tuzemtsy!' ['To Native Citizens!'] TK 19 th March 1917 No.63; this is cited in Khalid Muslim Cultural Reform pp.249-50, although he does not really do justice to some of the ambiguities of Lykoshin's position here.
} 
'Sufism, Panislamism and Information Panic: Nil Sergeevich Lykoshin and the aftermath of the Andijan Uprising' Past \& Present No.214 (2012) pp.255 - 304

making anti-Russian speeches and demanding control of the city municipality, and warned that in the city Duma of Tashkent, representation in proportion to the makeup of the population of the city (which, he wrote, seemed inevitable) would lead to a substantial native majority, with unpredictable consequences. Notwithstanding this scepticism, on August $18^{\text {th }}$, in a strange turn of events, he was proposed as head of the city of Tashkent by the conservative Muslim party which dominated the city Duma, 'Ulama Jami'yati. ${ }^{131}$ This provoked howls of protest from the Jadids (Muslim reformers) and Socialists in the Duma, ${ }^{132}$ and another lengthy self-justificatory letter from Lykoshin to the editor of

\section{Turkestanskii Kur'er.}

'I once again affirm, that under the old government for many years I served Turkestan and Turkestan alone. Entering service here as a young, 19-year old officer I studied this region intently, I know its language, I know the life of the natives, as it really is. [...] Personally I do not shrink from this responsibility: to one who has nothing to be ashamed of in his former affairs, there is no need to fear the epithet 'former governor'.

In agreeing to the proposition of the party of the "ulema", I with gladness and hope thought that in the duma, the organ of urban self-government, called to revive Tashkent, my knowledge would stand me in good stead, and that there perhaps I would not be the last worker.

But if the parties, which have begun to engage in ceaseless struggle, have a view to make the duma the arena for such struggles in the future, then, of course, both my gladness and my hopes are unfounded...'133

Thereafter he wisely kept a lower profile. Although his activities throughout the remainder of 1917 are obscure, Lykoshin survived the Bolshevik takeover and was subsequently recruited as an 'expert' on Turkestan by the new regime, working as a translator and teacher. For a while he taught Turkic languages and ethnography at the new 'University of the toilers of the East' established in Tashkent in 1918, and later became a professor in Samara, on the Volga, where he died in $1922 .{ }^{134}$

\section{Conclusion}

The number of important questions which arise from this one (admittedly substantial) file gives some indication of the riches which remain untapped in Central Asian archives. On the simplest level this series of petitions, correspondence and witness statements give a series of glimpses into the murky politics of the 'native administration' of Russian Turkestan, the factionalism, feuding and fraud of which were simultaneously very difficult for the Russians to understand or control, and immensely wasteful of

\footnotetext{
131 Jeff Sahadeo suggests that this was a tactical decision by 'Ulama Jami'yati to cement the existing social order in Muslim Tashkent by seeking conservative Russian allies: Russian Colonial Society in Tashkent (Bloomington, IN, 2007) pp.196, 277; see also Buttino Revolyutsiya naoborot pp.166-7; I am not sure Buttino is justified in referring to Lykoshin as a 'monarchist', however.

132 'Gorodskaya Duma' ['The City Duma'] TV 20"th Aug. 1917 No.122; 'Gorodskaya Duma' TK 20"th Aug. 1917 No.186

133 Nil Lykoshin 'Grazhdanin Redaktor!’ TK 28 ${ }^{\text {th }}$ August 1917 No.188

134 TsGARUz F. R-2499 Op.1 D.4 8/02/1919 11.2-3; Lunin Istoriografiya pp.221-2
} 
'Sufism, Panislamism and Information Panic: Nil Sergeevich Lykoshin and the aftermath of the Andijan Uprising' Past \& Present No.214 (2012) pp.255 - 304

administrative time. The likelihood is that this entire lengthy file and the 18-months-worth of correspondence and investigations it contains is the product of some half-understood dispute between native officials, and whilst the means used to attract the colonial authorities' attention here were particularly elaborate and imaginative, in other respects it is an entirely typical example of the sort of paperwork which dominates the Chancellery records of Russian Turkestan: fluent and elaborate accusations, allegations and petitions, months of investigation, and very little to show at the end of it. ${ }^{135}$ In the end the only concrete outcome from the administration's point of view was that Lykoshin's investigations uncovered what was probably quite a lucrative little cottage industry producing forged seals in Sairam: the investigation of the seals found in Mullah Muhammad Yusuf's box revealed that they were excellent copies of the seals of former rulers and qazis of Kokand, dated between 1815 and 1871, though mostly from the 1840s. Indeed their quality was so much superior to the crude 'royal' seal on the 'Afghan' letter that they probably indicated that Mullah Muhammad Yusuf was not responsible for that particular forgery. ${ }^{136}$

With its references to cattle-raiding and and the near-certainty that Kalkabekov had bribed the settlers of Vysokoe to conceal the fact that the 'Afghan' letter had originated with him, this file also contains some intriguing material on everyday relations between Russian settlers and Kazakhs at the turn of the century, a subject that remains under-researched but is of vital importance to understanding the brutal events in Semirechie and Syr-Darya province in 1916-17. The fact that the two Russian settlers who were interrogated clearly considered that their story of visiting the neighbouring aul in search of koumiss would seem natural to the colonial authorities itself suggests that settlers were partially dependent on their Kazakh neighbours, and were willing to experiment with the local (or indeed any) form of alcohol, but there is much else in the account which highlights a certain unease between these two groups: the readiness of the mother and daughter to believe that the Kazakhs who lived all around them were indeed preparing to

\footnotetext{
135 See Morrison Russian Rule in Samarkand Chapter 5; I should add here that whilst there is nothing in the file to indicate that any prosecutions were made, or any record in the file inventories of the Chimkent and Aulie-Ata Magistrates' Courts of any prosecution of those involved, the likelihood is that any case would have been brought in the Tashkent Regional court, whose files are held in the Central State Archive of the Republic of Uzbekistan, where I have not been able to work since 2003. On the other hand, had there been a prosecution, it seems probable that the original of the 'Afghan' letter, together with other evidence in the file, would have made its way from Chimkent to Tashkent.

136 TsGARKaz F.124 Op.1 D.7 Protokol No.13 16/09/1899 1l.117-8; this type of sharp practice seems to have been common in the southern steppe: in 1897 a forged 'Timurid' waqfnama (deed of endowment) for the great shrine of Khwaja Ahmad Yasavi in nearby Turkestan was presented to the Russian authorities, and it would continue to deceive orientalists until the 1940s. See Devin DeWeese 'The Politics of Sacred Lineages in $19^{\text {th }}$ Century Central Asia' International Journal of Middle-East Studies 31/4 (1999) pp.508-9
} 
'Sufism, Panislamism and Information Panic: Nil Sergeevich Lykoshin and the aftermath of the Andijan Uprising' Past \& Present No.214 (2012) pp.255 - 304

slaughter them all, or the initial belief of the villagers in Mambet Kalkabekov's tale of hidden weapons. On this occasion everything may have ended happily in vodka-fuelled celebrations, but within seven years the opening of a direct rail link across the Steppe with European Russia, and the increasingly aggressive policies of the Pereselencheskoe Upravlenie (Resettlement Administration) would lead to a much greater influx of Russian settlers, putting ever greater strain on relations with the nomadic population. It is true though that the inter-ethnic violence of 1916 was much worse in Semirechie than in Syr-Darya province.

It cannot be denied either that the file sheds an interesting light on the nature of rumours about the Andijan rising elsewhere in Turkestan, and on the stories which circulated about the ishan before and after his death. Whilst the story about the ishan smuggling firearms to the Kazakhs of the Chimkent and Aulie-Ata districts spun by Mambet Kalkabekov was almost certainly a fiction, it seems unlikely that Kalkabekov could have entirely invented all the stories he relayed about the ishan, his miracles and his spiritual authority. Whilst it is perfectly possible that he obtained them from Russian sources, he does not seem to have been literate in Russian, and they resemble those related in the Manaqib-i Dukchi Ishan, which was written and circulated in order to drum up support for the attack by demonstrating the ishan's supernatural power to slay his enemies and reward his followers, and which he would have been able to read. ${ }^{137}$ It seems possible, at least, that the idea occurred to him because he came into contact with a version of this text or some other form of religious propaganda distributed by the ishan's followers before the uprising.

Kuyuk canton, where Kalkabekov lived, lay at the southern edge of the Aulie-Ata district and bordered on regions with a substantial population of Kyrgyz, amongst whom there may well have been some followers of the ishan. There is also the intriguing reference to the mysterious 'Tugulbai', who was supposed to make regular trips across the passes to the Ferghana Valley, and it is possible that there was more general communication between the Kazakhs of the southern steppe and the settled and nomadic peoples of the Ferghana Valley than is sometimes realised. Izrail-Ishan, who was eventually exonerated of similar accusations of fomenting revolt in 1895-6, had been born in the village of Darbak in the Aim canton of Andijan district, but one of his three wives was a Kyrgyz of the Aulie-Ata district, and he clearly had an extensive following amongst both the Kyrgyz and Kazakhs of the area. When interrogated he said that for the previous

${ }^{137}$ Anke von Kügelgen 'Predisloviya' in Babadzhanov Manaqib p.14; Komatsu 'The Andijan Uprising reconsidered' pp.50-1 
'Sufism, Panislamism and Information Panic: Nil Sergeevich Lykoshin and the aftermath of the Andijan Uprising' Past \& Present No.214 (2012) pp.255 - 304

thirty years, almost since he was recognised as an ishan in succession to his father at the age of 16, he had come to the Aulie-Ata district every two years, when the Kyrgyz made their winter migration to lower ground there. ${ }^{138} \mathrm{He}$ was accompanied by followers from Osh and Andijan, whilst some of the Kyrgyz interrogated by the Russians had accompanied him back from Aulie-Ata to Andijan when he returned. ${ }^{139}$ Whether these close religious links were a product of the period when the entire region was under the rule of Kokand is unclear, but it is possible that this common political heritage was also important: certainly in 1875, at the time of the (at least semi-religiously inspired) rebellion against the last Khan of Kokand, Khudoyar, in the Ferghana Valley, the Aulie-Ata district Commandant had reported considerable alarm and agitation in his district. ${ }^{140}$ Add to this the fact that, as a senior member of the Tsarist 'native administration', Isa Batyrbekov had retained at least some of the influence his father wielded as a Kokandi dadkhwah, and it seems possible that the defunct khanate's ghostly influence lingered on even in steppe regions where it is generally thought to have had very shallow roots.

Although we cannot know how many other Kazakhs had heard of the ishan and his miracles, this does cast some doubt on Manz's interpretation of the uprising as a localised, tribal revolt. ${ }^{141}$ Whilst the violence of the uprising itself did not spread beyond Andijan, Osh and the immediate locality, this file suggests that at a lower level of society the stories of the Dukchi Ishan's miracles and his moral leadership had more considerable resonance, and that they spread well beyond the religious community he had established in Eastern Ferghana, and the Uzbeks and Kyrgyz who actually followed him in the attack on the Andijan garrison. Hisao Komatsu has already demonstrated that advance knowledge of the uprising reached as far as Samarkand and Tashkent, whilst Babajanov writes that the relative peace and new forms of communication brought by Russian rule in Turkestan may actually have facilitated the spread of the ishan's message. ${ }^{142}$ The evidence from this file certainly reinforces the idea that the ishan had a certain religious standing and moral authority beyond the borders of the valley, and was not simply a local political leader.

What is more certain is that Kalkabekov understood very well how effective stories about the Dukchi Ishan's influence over the Kazakhs would be as a hook to catch

\footnotetext{
138 TsGARKaz F.433 Op.1 D.1 Protokol 02/03/1895 11.23-4

${ }^{139}$ Ibid 1l.49-51ob

140 RGVIA F.1396 Op.1 D.91 'O voennykh deistviyakh v Kokandskom Khanstve' ['On military activities in the Kokand Khanate'] Aulie-Ata D. C. to the Military Governor of Syr-Darya Province 18/08/1875 11.140-1 ${ }^{141}$ Manz 'Central Asian Uprisings' pp.269-7

${ }^{142}$ Komatsu 'The Andijan Uprising Reconsidered' pp.30, 42-3, 55; Babajanov 'Andizhanskoe vosstanie 1898 goda i "musul'manskii vopros" v Turkestane' pp.186-7
} 
'Sufism, Panislamism and Information Panic: Nil Sergeevich Lykoshin and the aftermath of the Andijan Uprising' Past \& Present No.214 (2012) pp.255 - 304

Russian official attention, and a weapon to use against his enemies. As for the idea of forging and circulating a letter which supposedly came from Amir 'Abd al-Rahman Khan or his son, it seems more than likely that this was the product of familiarity with Russian official thinking on the causes of the Andijan Uprising, perhaps even with the official report itself, whose reference to 'emissaries' from the Afghan Amir was so accurately echoed in the letter's contents. This in turn points to the involvement of someone very familiar with the ins and outs of Russian officialdom, such as the wealthy former canton administrator Isa Batyrbekov, though we cannot be certain of this. Whoever precisely was responsible, the whole story demonstrates a remarkably canny ability to play on the twin Russian fears of backward Sufi 'fanaticism' and modern Pan-Islamism. Norihiro Naganawa has noted similar tactics amongst Tatars in Kazan province, where in 1905 a group of villagers seeking to have their mullah removed claimed that he had been a follower of the Dukchi Ishan (the mullah responded by claiming his accusers were panislamists).${ }^{143}$ However, this was in a region which had been under Russian rule for well over three hundred years, where a degree of familiarity with the Russophone public sphere is unsurprising. To find a similar phenomenon (on a much more elaborate scale) amongst the Kazakhs of a region that had only been conquered forty years before is more unexpected. If the Russians often complained that Central Asian society was a closed book to them (it was ignorance which produced their anti-Islamic paranoia, after all) some Central Asians, at least, clearly understood the mentality of their colonial rulers only too well, and were able to manipulate their fears to their advantage with relative ease. Whether this should be seen as the emergence of a 'single colonial society' is debatable, but clearly after thirty years of Russian rule some Turkestani Kazakhs were very familiar with the Russian colonial public sphere, its obsessions and prejudices. ${ }^{144}$ Ironically enough, in this respect at least, Lykoshin's pious aspiration for greater rapprochement between Russian and native society was bearing fruit - but not in the manner or on the terms which he had envisaged. Rather than superior Russian culture opening up the 'closed' society of Central Asia to the Russian gaze, it was the 'natives' who were gaining a superior understanding of the Russians.

All these conclusions are quite speculative, given that this file only provides us with a series of vignettes of Kazakh and settler life, and that it is a product of

\footnotetext{
143 Norihiro Naganawa 'Maktab or School? Introduction of Universal Primary Education among the VolgaUral Muslims' in Uyama (ed.) Empire, Islam, and Politics p.73

${ }^{144}$ My thanks to Paolo Sartori for suggesting that I make this point more forcefully. For an exploration of this idea see Jürgen Paul 'Review Essay: Recent monographs on the social history of Central Asia' Central Asian Survey 29/1 (March 2010) pp.119-130
} 
'Sufism, Panislamism and Information Panic: Nil Sergeevich Lykoshin and the aftermath of the Andijan Uprising' Past \& Present No.214 (2012) pp.255 - 304

interrogation and, in part, outright and deliberate fabrication. We are on firmer ground when we consider what this file, and more generally the Russian response to the Andijan Uprising, can tell us about the 'official mind' of Russian administrators in Turkestan, their views of Islam, and of their own purpose and civilising mission in the region. It shows clearly enough how islamophobic paranoia could blind officials to the obvious and set them off on a wild-goose-chase which ate up time and valuable resources. Ultimately even an outstanding and relatively liberal officer like Lykoshin, with his friendships amongst elite Muslims, his fluent knowledge of local languages, and, not least, his shrewdness and common-sense in untangling a mare's-nest which had occupied his counterparts for months, was not immune to the usual Russian - or perhaps more broadly, colonial prejudices about the backwardness and 'fanaticism' of the local population. His continued belief that it was Islam which formed the great stumbling-block to assimilation and the most profound threat to the stability of Russian rule blinded him, as it did almost everyone else in the Tsarist administration, to the more profound grievances of Turkestan's colonised population over land, water and Russian settlement, which were brought to the fore when the conscription decree was issued in July 1916. When a really serious rebellion came to Turkestan that year, it was not as a war of religion. 